\title{
Strategies for the development of volcanic hazard maps in monogenetic volcanic fields: the example of La Palma (Canary Islands)
}

\author{
José M. Marrero ${ }^{1 *}$ (D), Alicia García², Manuel Berrocoso ${ }^{3}$, Ángeles Llinares ${ }^{1}$, Antonio Rodríguez-Losada ${ }^{4}$ \\ and Ramón Ortiz ${ }^{2}$
}

\begin{abstract}
Traditionally volcanic-hazard assessments have been applied to stratovolcanoes, where volcanic hazard maps represent important tools for volcanic crisis management and land-use planning. In recent years, several improvements have been made for monogenetic volcanic fields focused on, among other things, the development of spatial models to deal with one of the main problems in these areas, namely the unknown vent location. However, volcanic hazard maps of monogenetic volcanic fields present some significant differences with respect to those developed for stratovolcanoes, including the fact that they commonly represent multiple eruptive processes spread over the possible vent opening area. Likewise, the scientific communication of the volcanic-hazard assessment and how this information is comprehended are critical issues in the development of mitigation strategies for monogenetic volcanic fields.

In this research, we focused on developing volcanic hazard maps using simple numerical hazard models in combination with a random approach for vent location to cover the whole vent opening area. We added some spatial methods to better manage potentially affected areas. The maps were designed for use in a digital environment (Geographic Information System) by Civil Protection professionals in high-risk monogenetic volcanic fields on small oceanic islands. The methodology presented does not use susceptibility base maps for hazard assessment to avoid possible underestimation of low probability areas by Civil Protection. The methodology represents an attempt to respond to the most important questions of where, when and how a new eruption might take place in a monogenetic volcanic field. The example presented here was developed for La Palma (Canary Islands).
\end{abstract}

Keywords: Hazard assessment, Expected eruptive scenario, Hazard map, Monogenetic volcanism, La Palma, Canary Islands

\section{Introduction}

Volcanic-hazard assessments maps constitute a well-used representative tool in hazard assessment and can be useful for land-use planning and the development of mitigation strategies. Hazard maps have been developed since the 1960s, mainly to deal with the threat of stratovolcanoes, and are typically based on the volcanoes' past eruptive history, geological setting and geographical environment

*Correspondence: josemarllin@gmail.com

${ }^{1}$ REPENSAR, Camino de Orellana, Quito, Ecuador

Full list of author information is available at the end of the article
(Scott 1989). Mount St. Helens (USA) and Nevado del Ruiz (Colombia) are important examples (Crandell and Mullineaux 1978; Parra and Cepeda 1990; Voight 1990). This approach is based on mapping possible hazards and is still widely used nowadays (see Servicio Geológico Colombiano (2015); Mothes et al. (2016a, b)).

The first computerized hazard models were also introduced around the 80s (e.g. for pyroclastic surges, (Sheridan and Malin 1983)) and were specifically developed for areas where there was a general lack of geological information (Burt et al. 2001). Currently, very sophisticated hazard models can be found (e.g. for ash fall, 
Macedonio et al. (2008); Folch et al. (2009)) but there are also simpler models that are designed to obtain faster multiple eruptive scenarios using fewer parameters and less complex computer system resources (e.g. for lava flow, ash fall and pyroclastic density current, (Felpeto et al. 2007)). Both types of models may be used to define the impact area in both long and short-term forecasts, and to carry out drills to manage the effects of a possible future crisis (Zuccaro et al. 2008, Marrero et al. 2013). They are often validated by simulating volcanic hazards associated with past eruptive events (Crisci et al. 2004). Frequently, for hazard maps, the most significant volcanic hazards are taken into consideration, with most probable or worst possible scenarios defined by the scientific committee (De la Cruz-Reyna and Tilling 2008). To define the most probable eruptive scenarios in terms of their expected volcanic activity as well as their spatial and temporal probability, several methodologies have been developed using the Bayesian approach (Marzocchi et al. 2008), expert elicitation (Aspinall 2006), or a combination of both, together with assessment of monitoring data (Woo and Marzocchi 2014). Temporal probability is more critical in areas where future vents are unknown, such as in monogenetic volcanic areas (Becerril et al. 2013) or calderas (Bevilacqua et al. 2015), but sometimes even at stratovolcanoes (Cappello et al. 2012). At present, the development and management of local (Bartolini et al. 2014) and worldwide volcano databases (e.g., (Newhall et al. 2017)) have attracted the interest of the scientific community on account of their potential application in improving statistical analysis used in eruptive scenario definitions and in forecasting eruptive activity during volcanic crisis. However, these approaches and the methods implemented are highly dependent on the quantity and quality of the data available in the databases.

At stratovolcanoes that pose a high risk for the populated areas, worst possible scenarios are more frequently used in volcanic hazard assessment. In these contexts, most probable scenarios tend to be less useful in volcanic hazard management on account of the size (smaller) and the frequent absence of population close to the summit area (see Cotopaxi volcano, Mothes et al. (2016a)). However, for high-risk monogenetic volcanic fields (Németh and Kereszturi 2015), and depending on the type of volcanic hazard, both the most probable and the worst possible scenarios are important. In some monogenetic volcanic areas, the lack of large volcanic edifices may allow people to live in close proximity to a potential eruptive vent. In others, such as small volcanic islands, people are often scattered over the volcano edifice.

Hazard maps for stratovolcanoes are related to specific scenarios that may occur from one vent location. However, conceptually, global hazard maps developed for monogenetic volcanic fields are completely different because they usually cover multiple vent locations per hazard type. In this case, they represent a combination of thousands of eruptions with no relation to one another at superficial level. This fact makes it even more difficult not only for the decision-makers and for Civil Protection professionals to understand the complexity of the situation but also, and more significantly, for the local community who, as result, require specific communication strategies.

The manner in which volcanic hazard assessment in both stratovolcano and monogenetic volcanic field settings is conveyed to decision-makers and just how easily comprehensible this information is are also critical issues in both short and long-term forecasts (Marzocchi et al. 2012). These critical issues affect landuse planning, emergency plans and procedures, together with the design of long-term mitigation strategies and short-term decision-making processes. Decision-makers must go through a learning process to understand the hazards they face together with their probable outcomes if they are to develop the best mitigation strategies and make the right decisions (Doyle et al. 2014). However, the more complex the scientific information, the greater the effort that scientists have to make when relaying said knowledge accessibly. So collaborative training processes are necessary together with the search for new ways of establishing and sustaining dialogue to improve decision-making processes (Doyle and Johnston 2011). This is especially important in areas with a long repose period where there may be a general lack of experience in volcanic crisis management (Marrero et al. 2015). Authorities generally also prefer to use hazard maps in static formats (PDF, JPEG, etc.) for the decision-making process and as a communication tool (Thompson et al. 2015). However, hazard maps are also commonly given the consideration of legal documents, sometimes serving as the basis for their direct inclusion in Emergency Plans (Marrero et al. 2015) or territorial planning.

The aim of this research is to develop volcanic hazard maps using simple numerical models for volcanic hazard assessment. Our approach does not use susceptibility maps, in order to avoid possible underestimation of low probability areas by Civil Protection. Instead, we have opted for a random model to represent the spatial distribution of vent location in both lava and pyroclastic flow simulations as explicitly addressed herein in the subsection relating to Definition of the spatial zoning approach and the use of a random model. The methodology has been developed for high-risk monogenetic volcanic fields on small islands and was designed for use by Civil Protection personnel. The methodology is an attempt to respond some important questions as where, when, how a new eruption may take place in a monogenetic volcanic field. We should underline here that this 
proposed approach has not been tested by the authors in collaboration with the local Civil Protection professionals as would have been desirable. The example presented here is a case study of La Palma (Canary Islands). The hazard maps were submitted to Civil Protection in November 2013, and were available for a time on a Web Map Server of the Canary Autonomous Government (http://idecan2. grafcan.es/ServicioWMS/Riesgos/Volcanico). However, a new hazard assessment study is underway at present for the whole of the Archipelago meaning that the current work is no longer available to the general public. Thus, we have provided a version of some of the hazard maps in Additional file 1.

\section{Framework}

The philosophy underpinning this work is that it should facilitate an understanding of the expected volcanic hazards that Civil Protection may face in the case of an eruption. It is also designed to be applied in places where the location of the next vent is either totally undetermined or highly uncertain, and where people live very close to potentially affected areas. We also consider that volcanic hazard maps based only on the study of natural phenomena (volcanic activity, geologic background, etc.) are insufficient to the task of adequately managing volcanic crises in high-risk contexts.

The framework is divided into three important steps: 1) the definition of Expected Eruptive Scenarios (EES) based on the geological background; 2) the use of a spatial zoning approach to better understand the characteristics of the area potentially affected by the expected volcanic activity; 3) and a volcanic hazard assessment using simple numerical models. This information is complemented by a clear and simplified hazard map report that includes terminology and methodology while identifying problems and offering some positive recommendations to aid decision-makers. It is important to highlight the fact that we developed several hazard maps with the aim that these be used in a digital environment (Geographic Information System) rather than as printable documents. This approach allows us to manage long-term hazard maps, avoiding visual saturation due to accumulated information.

\section{Methodology}

In this research, three volcanic hazard models were used (see, Felpeto et al. $(2001,2007)$, all in command lineoriented C ANSI programs via Linux (Marrero et al. 2013): 1) A maximum-slope lava flow model based on Monte Carlo algorithms where the output shows the probability of occupancy of each grid-cell by lava flow; 2) A pyroclastic flow model based on the Energy Cone model (Hsü 1975; Malin and Sheridan 1982; Sheridan and Malin 1983), that links source location with the distal limit reached by the deposit and where the output represents the energy loss expressed in terms of relative deposit thickness; and 3) an advection-diffusion model (Folch and Felpeto 2005) used to estimate ash fall and the expected proximal deposit thickness. A 5-meter resolution DEM was used together with GRAFCAN base cartography (GRAFCAN 2009).

\section{Step 1: Definition of expected eruptive scenarios}

We define the Expected Eruptive Scenario (EES) as the type of activity that may take place in an active volcanic area in accordance with its past eruptive history and geological setting or by comparison with other similar volcanic areas when insufficient local information is available. The EES depends on the characteristics of the magma, vent location and volcanic system and the outcomes are described in detail and presented in a simplified scenario-tree to allow for clearer understanding.

\section{Step 2: Spatial zoning approach}

We consider that the unknown vent location in monogenetic volcanic fields makes it necessary to adopt specific approaches toward improving volcanic-hazard management in these areas. Therefore, a spatial zoning approach should be applied with the following elements (Fig. 1 and Table 1):
1 Vent Opening Area (VOA)
2 Vent Opening Sector (VOS)
3 Risk Management Sector (RiMS)

A VOA is the area where a possible new vent may appear. It is important to note that the VOA does not represent the area affected by a possible eruption meaning that volcanic hazards may extend further. To obtain a VOA, an understanding of the geological setting is required.

The VOS is a zonation of the VOA with various different aims. Initially, the VOS allows the researcher to distinguish the different areas where variations of the EES may be appropriate. The VOS also helps to organize the hazard assessment of some of the volcanic hazard types, thereby avoiding saturation of information during the hazard simulation. The VOS depends not only on the geological setting but also on the type of EES. Setting the limits between different VOS is an important task. In this sense, the best approach is to use gradational zones, although many decision-makers prefer clearly defined linear limits as has been highlighted by Thompson et al. (2015).

RiMS are directly related to the concept of the hazard map as an official printable document. The RiMS are used optionally when the scale selected makes it necessary to divide the threatened area over several different maps. In such cases, the criteria used are 


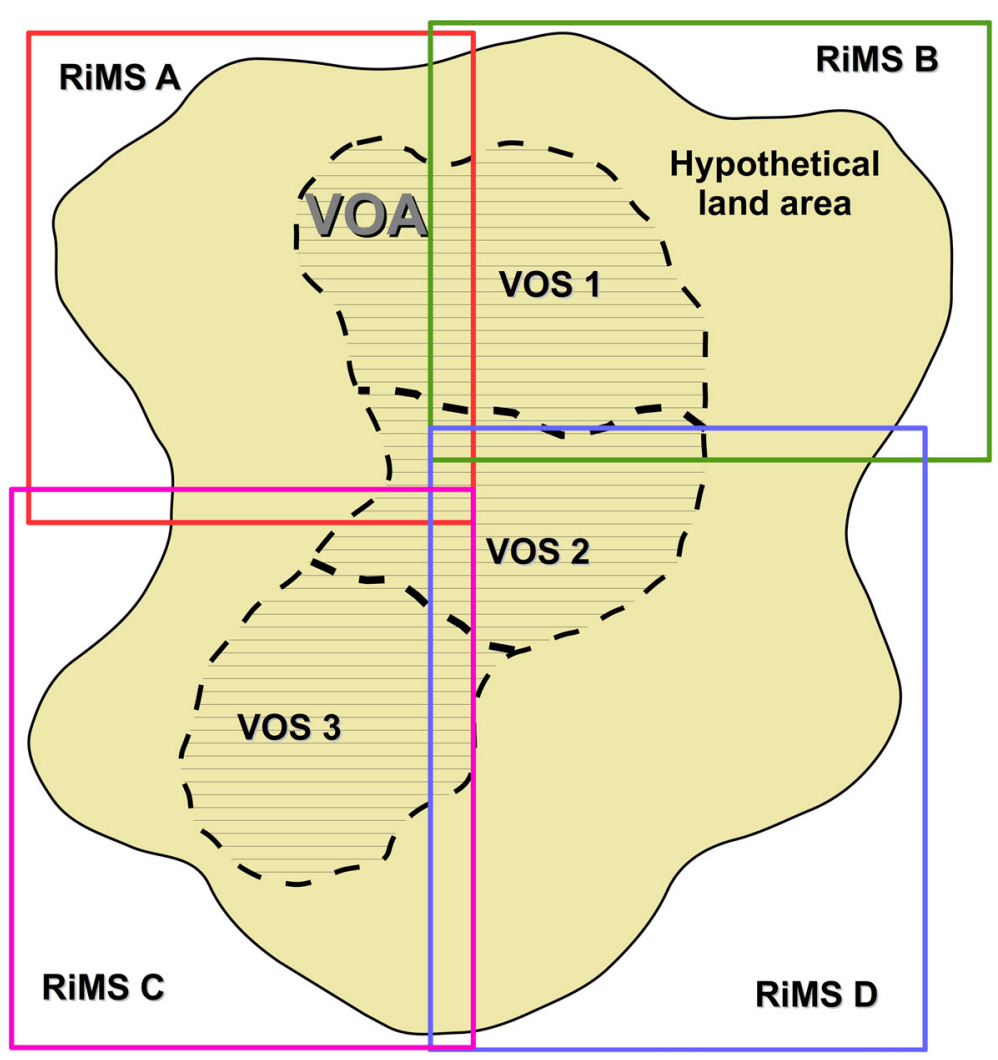

Fig. 1 Schematic distribution of VOA, VOS and RiMS for a hypothetical volcanic field. See text for discussion

different to those used for defining VOS (i.e., administrative limits, geographic features such as valleys, etc.) and allow for specific operational areas to be designated on different hazard maps to facilitate risk management for decision-makers.

Table 1 Table of main acronyms and type of identifiers used in this work

\begin{tabular}{|c|c|c|c|}
\hline Acro. & Meaning & Description & Identifier \\
\hline EES & $\begin{array}{l}\text { Expected } \\
\text { eruptive scenario }\end{array}$ & $\begin{array}{l}\text { Type of expected } \\
\text { volcanic activity }\end{array}$ & $\begin{array}{l}\text { Combination of capital } \\
\text { letters and numbers (A, B1, } \\
\text { B2, B3, C1, C2, C3) }\end{array}$ \\
\hline VOA & $\begin{array}{l}\text { Vent opening } \\
\text { area }\end{array}$ & $\begin{array}{l}\text { Area where a } \\
\text { new vent can } \\
\text { take place }\end{array}$ & - \\
\hline VOS & $\begin{array}{l}\text { Vent opening } \\
\text { sector }\end{array}$ & Zoning of $\mathrm{VOA}$ & Numbers (0-4) \\
\hline RiMS & $\begin{array}{l}\text { Risk } \\
\text { management } \\
\text { sector }\end{array}$ & $\begin{array}{l}\text { Division of } \\
\text { printable hazard } \\
\text { maps }\end{array}$ & $\begin{array}{l}\text { Lowercase letters ( } a, b, c \text {, } \\
d, e, f, g)\end{array}$ \\
\hline $\operatorname{lnv}$ & Input vent & $\begin{array}{l}\text { Possible vent } \\
\text { location }\end{array}$ & - \\
\hline SHS & $\begin{array}{l}\text { Single hazard } \\
\text { scenario }\end{array}$ & $\begin{array}{l}\text { Hazard model } \\
\text { output }\end{array}$ & - \\
\hline $\mathrm{CHS}$ & $\begin{array}{l}\text { Compound } \\
\text { hazard scenario }\end{array}$ & $\begin{array}{l}\text { Combination of } \\
\text { multiple SHS }\end{array}$ & - \\
\hline MHS & $\begin{array}{l}\text { Multiple hazard } \\
\text { scenario }\end{array}$ & $\begin{array}{l}\text { Combination of } \\
\text { different SHS }\end{array}$ & - \\
\hline
\end{tabular}

Step 3: Hazard features

In the case of hazard assessment, we distinguish between the following features (see Table 1):

1 Input Vent (InV)

2 Single Hazard Scenario (SHS)

3 Compound Hazard Scenario (CHS)

4 Multiple Hazard Scenario (MHS)

The Input Vent (InV) is the source, expressed in geographic coordinates, of a probable future vent that will be used in the hazard model as input data. In general, different approaches may be used to define the spatial distribution of InVs for relatively small and high-risk volcanic islands. In such cases, spatial vent distribution may follow the geological structures (Bartolini et al. 2013; Becerril et al. 2013) or a regular or random model may be applied.

A Single Hazard Scenario (SHS) is the output of the hazard model used (lava flow, pyroclastic flow, etc.) once the simulation process has been completed. The SHS relates to one single InV and one type of volcanic hazard alone. An example of SHS can be shown in Crisci et al. (2004), where several simulations were carried out to reproduce the 1991 lava flow from the 1991-1993 eruption on Etna. 
The Compound Hazard Scenario (CHS) is obtained from the sum (or combination) of a geographic layer of multiple SHS. To describe the CHS, we can use that the example of (Pistolesi et al. 2015), where various different lahar scenarios were simulated and then combined on one global map.

The Multiple Hazard Scenario (MHS) aims at evaluating the impact area that may be generated by a combination of different volcanic hazards, that is, by different types of CHS or SHS (Fig. 2). However, in monogenetic volcanic fields, this approach is only useful when simulating specific eruptive scenarios from one single volcano. An example of a MHS can be observed in the hazard maps of Cotopaxi volcano (Ecuador, Mothes et al. (2016a, b)) where several volcanic hazards are combined to show the potentially affected areas (lahar, pyroclastic flows, ash fall, etc.).

\section{Requirements for an accompanying report}

In cases where there is scarce collaboration between the researchers and the authorities (Marrero et al. 2015), where the technicians are constantly changing (Newhall et al. 1999), or where the hazard maps are designed solely for the authorities and not for the general public (as was the case here), we believe that it is important to explain the hazard maps using an accompanying report. These reports may offer a clearer understanding of the hazard maps themselves as they explain not only the EES and the volcanic activity but also how the hazard maps were designed and developed (Thompson et al. 2015). Although reports may vary, we believe that some elements should be addressed. First, they should include a glossary of all the concepts that the authorities need to understand in order to fully comprehend the hazard maps, such as hazard, risk, vulnerability, uncertainty, probability and forecast. Then, they should give a brief description of the eruptive history and geological context of the study area. Where, how, and when are the questions that ought to be answered as clearly as possible, including the uncertainty level of each (if possible), together with definition and clarification of the EES and volcanic activity. The methodology used to develop the hazard maps and the choice of assigned parameters should also be included, ideally described as simply as possible for the hazard model to be easily comprehensible. When volcanic hazard information is available in digital format there should be a clear explanation of how to use it. Finally, and with a view to improving hazard assessment, recommendations should be made for future work in those areas where a general lack of knowledge has been observed.

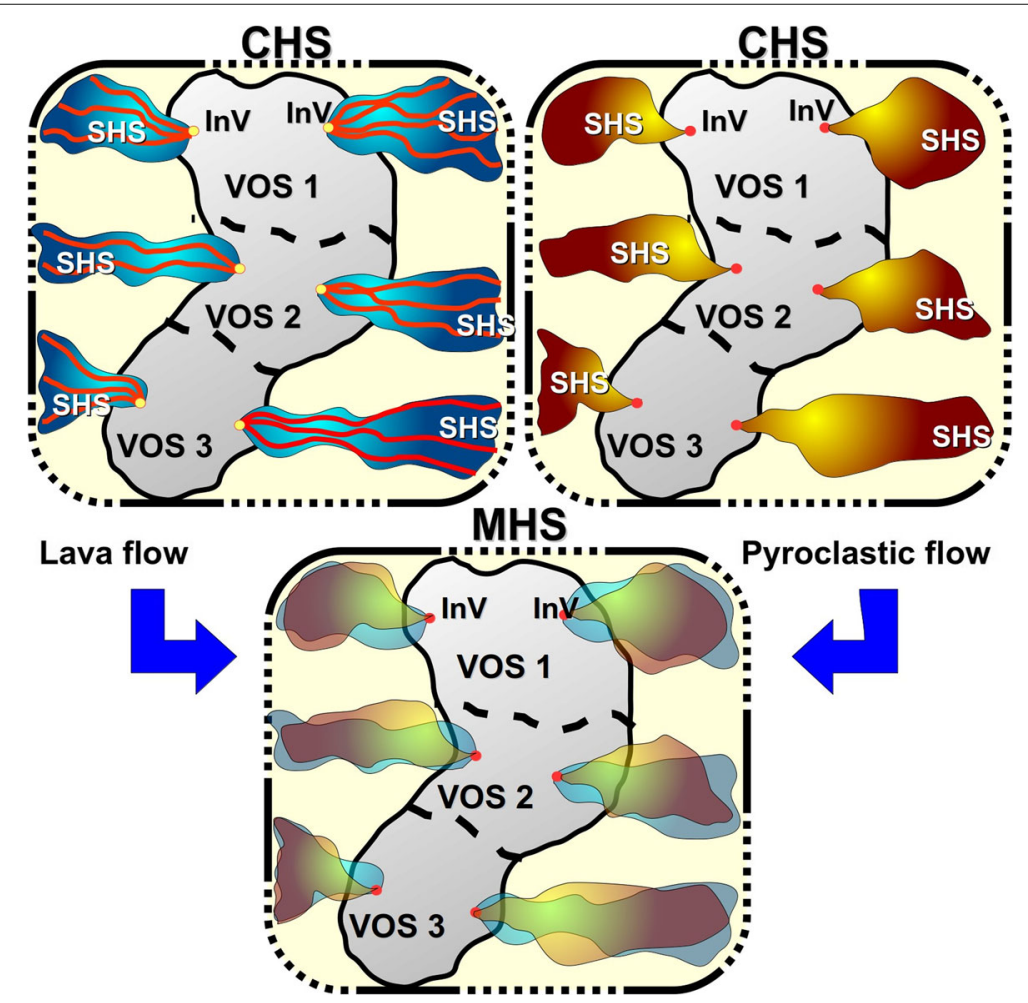

Fig. 2 Examples of combined SHS (lava flow top-left, PDF top-right) to generate CHS. The combination of different types of CHS produces an MHS, but in basaltic volcanic fields this combination is not useful. Thus, hazard maps can be generated from the CHS for long-term or from the MHS for short-term when addressing one specific volcanic scenario 


\section{Volcanic hazard assessment}

\section{La Palma: geographical setting and eruptive history}

The island of La Palma $\left(28.7^{\circ} \mathrm{N} ; 17.85^{\circ} \mathrm{W} ; 2423 \mathrm{~m}\right.$ highest elevation, and a total area of $706 \mathrm{~km}^{2}$ ) contrasts geomorphologically between the northern and southern parts of the island due to the distribution of more recent volcanic activity in the latter. The northern areas are affected by intense erosion with a deep drainage network and high coastal cliffs. In contrast, the southern part of the island has an underdeveloped drainage network and lower coastal cliffs, although steep slopes exist in both areas. Several volcano-stratigraphic units have been identified (Abdel-Monem et al. 1972; Staudigel et al. 1986; Ancochea et al. 1994; Carracedo et al. 2001; Guillou et al. 2001; Singer et al. 2002). According to Carracedo et al. (2001) the first subaerial eruptive phase $(\sim 1.7 \mathrm{Ma})$ occurred in the north of the island, first giving rise to the Garafía volcano unit, and later to the Taburiente volcano unit $(\sim 1.2 \mathrm{Ma})$. On the southern flanks of the active stratovolcano, gravitational collapses have occurred over time. Volcanic activity then migrated southward ( $\sim 0.5 \mathrm{Ma})$ forming the Cumbre Nueva and Bejenado units.

Scandone et al. (2009) noticed that when evolved magma is present, most large volcano edifices are steeper, such as is the case in Taburiente volcano, leading to caldera formations and/or flank failures. Evolved volcanic deposits have been found, for example, at the summit of the Taburiente Caldera (2426 m) (Ancochea et al. 1994) (Fig. 3). The phonolitic rocks of Cumbre Vieja, dating from between 56 and $26 \mathrm{ka}$ (Carracedo et al. 2001), suggest the presence of small transitory evolved magma batches (Day et al. 1999) located at a depth of 7 to $11 \mathrm{~km}$ (Klügel et al. 1999, 2005). The interaction between the juvenile magma and these shallow batches might increase the volcanic explosivity (Andújar and Scaillet 2012). A correlation between this interaction and an increased level of seismic activity (frequency and magnitude) has been suggested, as reported during the Jedey eruption (XVI) (Johansen et al. 2005). In La Palma, some of the most recent eruptions followed the same upward path used by the evolved magmas in earlier eruptions (San Juan volcano 1949, (White and Schmincke 1999)).

The volcanic activity in the last $0.1 \mathrm{Ma}$ has been mainly dominated by Strombolian and phreato-Strombolian eruptions located in the N-S-trending Cumbre Vieja Unit (Carracedo et al. 2001) (Fig. 3). The eruptive return period for La Palma was assessed by Astiz et al. (2000) who established a range of between 50 and 100 years, with 7 eruptions in the last 600 years: $\sim 1480$, Montaña Quemada (Carracedo et al. 2001); 1585, the Jedey volcano (Romero 1990; Johansen et al. 2005); 1646, Tigalate or San Martín volcano (Romero 1990; Carracedo et al. 1996); 1677, San Antonio volcano (Romero 1990; Carracedo et al. 1996); 1712, Montaña Negra (Romero 1990; Carracedo et al. 2001); 1949, San Juan volcano (Klügel et al. 1999; White and Schmincke 1999); and 1971, Teneguía volcano (Afonso et al. 1974;Araña 1999). However, there is no detailed work with which to reconstruct the eruptive history of La Palma over the past 100,000 years. Moreover, the location of the deep magma plumbing system is not yet clear, so four volcano-tectonic models have been proposed (Fig. 4): in models $A$ and $B$ (Klügel et al. 1999; Klügel et al. 2000; Galipp et al. 2006) Cumbre Vieja is linked to a deep volcanic system located under the Taburiente Caldera (45-65 km deep according to, (MartínezArevalo et al. 2013)). Model $A$ proposes a vertical ascent of magma to form a shallow reservoir, from which magma is then driven towards the South. Model $B$ proposes a lateral migration of the deep system and then vertical injection processes; in Model $C$, Cumbre Vieja is considered as an independent edifice with its own deep magma emplacement system (Galipp et al. 2006); and in Model $D$ the magma emplacement zone could also be located further South, with a lateral migration toward the North (Camacho et al. 2009). The magmatic injection processes inferred in the case of the unrest and volcanic activity in El Hierro (2011-2013, (García et al. 2014)) correspond to a cone-injection model proposed by De la Cruz-Reyna and Yokoyama (2011). The cone-injection model provides an explanation for the mechanical problems related to horizontal migration of the deep volcanic system.

\section{Magmatic eruptions}

The recent eruptive style in La Palma has been predominantly characterized by lava flow emission and moderate explosivity (e.g. Teneguia 1971, (Afonso et al. 1974;Araña 1999)) located at medium elevations (Klügel et al. 1999; White and Schmincke 1999). However, for some eruptions in La Palma, two elements may have increased the explosivity: water interaction and evolved magmas (Klügel et al. 1999; White and Schmincke 1999). Moreover, there are other factors of a more general nature that must be taken into account, such as changes in the eruptive dynamism and/or different vents opening during an eruption (c.f. the San Juan eruption 1949 in La Palma, (Klügel et al. 1999; White and Schmincke 1999)) together with explosive phases masked by recently emitted material that may lead to possible underestimation of the explosiveness of the volcanic activity (Kereszturi and Németh 2012).

\section{Hydromagmatic eruptions}

The interaction between the magma and seawater or aquifers may increase explosivity (Wohletz 1983; Kokelaar 1986) depending on the mixing process (Wohletz 1983; Mastin et al. 2004) and the properties of the magma (Cas 1992). The hydromagmatic activity in La Palma tends to cluster in the summit area (Quesada et al. 1998; Klügel et al. 1999; White and Schmincke 1999; Carracedo et al. 


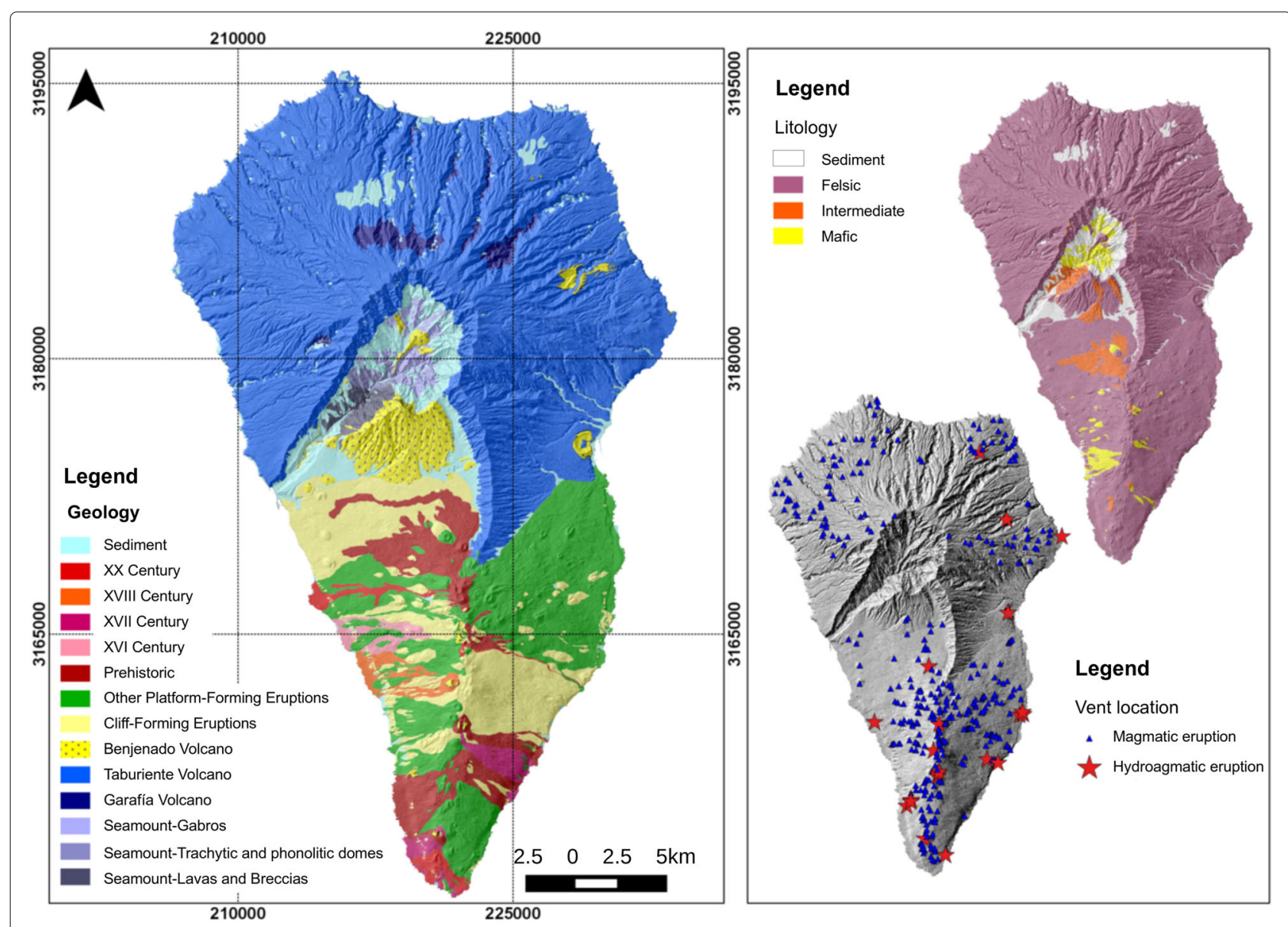

Fig. 3 Geological map of La Palma (map on the left) according to Carracedo et al. (2001). The top-right map is a simplified version of the geological map showing the main lithological units. The bottom-right map represents the distribution of cinder cones

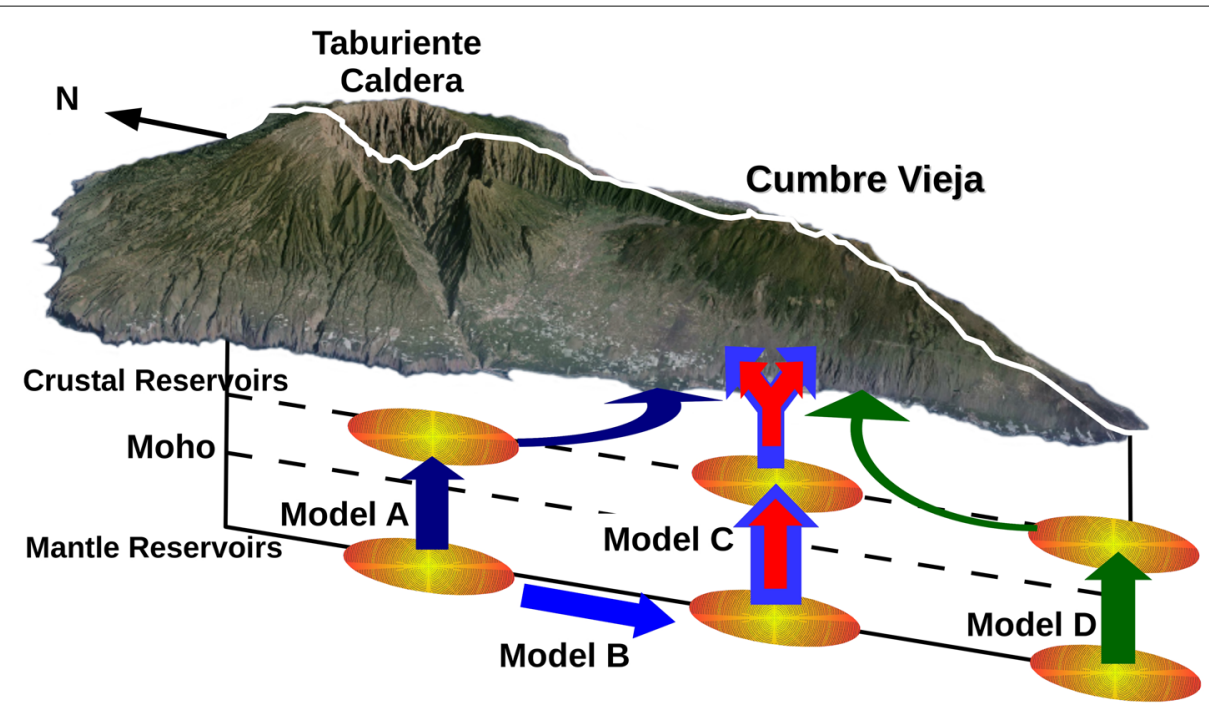

Fig. 4 Magma emplacement models for La Palma. See text for discussion 
2001) or near the coastline (Quesada et al. 1998; De la Nuez and Quesada 1999). In the Canary Islands, some of the volcanic crises in the past may have ended in a submarine eruption without any visible effects observed, such as was the case of the unrest in 1793 on the west coast of El Hierro (Hernández-Pacheco 1982; Villasante-Marcos and Pavón-Carrasco 2014) or the more recent submarine eruption in 2011 (López et al. 2012). Bathymetric studies available for the Canary Islands show multiple volcanic cones spread around the submarine slopes (Acosta et al. 2003, 2005). The internal dynamics of basaltic submarine eruptions may be similar to those occurring onshore but the eruptive style is also conditioned by external environmental factors, such as the hydrostatic pressure (Kereszturi and Németh 2012). According to Fisher and Schmincke (1984), the critical depth for magma fragmentation and explosive activity in basaltic volcanism is from 200 to $300 \mathrm{~m}$ deep although magma fragmentation may take place deeper down as the result of non-explosive activity (Cas 1992). This critical depth is found over a slim area surrounding La Palma (VOS 0), but is difficult to define because of the lack of high-precision bathymetric data near the coastline.

\section{Volcanic Risk management in La Palma}

In Marrero et al. (2015) and Ortiz et al. (2018) there is an extensive study of volcanic risk management in the Canary Islands and how it has evolved over the last 20 years. Although significant progress has been made, there is still much room for improvement in risk management due to the difficulties that are presented when carrying out the task in small and populated islands (McGuire et al. 2009). In the specific case of La Palma, that for years has been considered one of the islands where a new eruption could take place (Carracedo et al. 1998), the present study represents the first volcanic hazard maps to have been developed, and no risk assessment has been published as yet.

The last volcanic eruption took place in 1971 in the inhabited southern part of the island (Volcán Teneguía, (Afonso et al. 1974)). It was a moderate eruption, combining effusive and explosive phases over 24 days. The eruption took the lives of two people due to gas inhalation and the extent of the damage to infrastructure and land was limited. Tourists had the chance to visit the island without causing logistic problems and no scientific controversies were vented in the local media. Nowadays, however, the situation would be more complex, should a possible new eruption occur in the same area.

\section{Step 1: Definition of the expected eruptive scenarios for La Palma}

In line with the past eruptive history and geological setting, three global EES were considered: A and B located onshore and $\mathrm{C}$ offshore. These EES were divided according to expected volcanic hazards (B1, B2, B3) and depth of the sea (C1, C2 and C3) (Table 2) and presented in a treelike structure, using a similar pattern to that proposed by Newhall and Hoblitt (2002) (Fig. 5). The worst-case credible scenario was not taken into consideration here, but according to Carracedo et al. (1999); Day et al. (1999) and Ward and Day (2001) may be related to a potential giant landslide from the west flank of Cumbre Vieja.

\section{Main features of the proposed EES:}

- Vent opening distribution:We used a random model to represent the complexity of the spatial distribution of vent location that the monogenetic volcanic activity can produce.

- Eruptive style variability: The eruptive pattern may vary over an eruption or involve multiple vents, with violent explosive phases only occurring at some of the vents. When the eruptive pattern varies over an eruption, some EES cover the range from lower to higher explosive activity, thereby avoiding the use of many different EES for the same vent. If the eruption is characterize by multiple vents, and when the distance between vents is over $1 \mathrm{~km}$, it is advisable to use totally different EES.

- Expected volcanic hazards: The most common expected volcanic hazards in the EES for A, B1 and B2 (Table 2) are lava flows, ash fall, gas emission and, in some specific cases, block-and-ash flows, to which

Table 2 Type of EES and its main characteristics

\begin{tabular}{|c|c|c|c|c|c|}
\hline & EES Type & VEl & Column & Hazards & E. Impact A. \\
\hline$A$ & $\begin{array}{l}\text { Hawaiian magmatic } \\
\text { effusive eruption }\end{array}$ & $0-1$ & $0-1 \mathrm{~km}$ & $\begin{array}{l}\text { Lava flows, ash } \\
\text { fall, gases }\end{array}$ & $\begin{array}{l}1-2 \mathrm{~km} \text {, } \\
\text { longer } \\
\text { downstream }\end{array}$ \\
\hline B1 & $\begin{array}{l}\text { Hawaiian- } \\
\text { Strombolian, } \\
\text { magmatic } \\
\text { effusive-explosive }\end{array}$ & $1-2$ & $1-5 \mathrm{~km}$ & $\begin{array}{l}\text { Lava flows, ash } \\
\text { fall, gases, } \\
\text { blockandash }\end{array}$ & $\begin{array}{l}2-5 \mathrm{~km} \text {, } \\
\text { longer } \\
\text { downstream }\end{array}$ \\
\hline B2 & $\begin{array}{l}\text { Hawaiian- } \\
\text { Strombolian, } \\
\text { magmatic } \\
\text { effusive-explosive, } \\
\text { mechanical } \\
\text { interaction with sills }\end{array}$ & $1-2$ & $1-5 \mathrm{~km}$ & $\begin{array}{l}\text { Lava flows, ash } \\
\text { fall, gases, } \\
\text { blockandash }\end{array}$ & $\begin{array}{l}2-5 \mathrm{~km} \text {, } \\
\text { longer } \\
\text { downstream }\end{array}$ \\
\hline B3 & $\begin{array}{l}\text { Hawaiian- } \\
\text { Strombolian-Violent } \\
\text { Strombolian, } \\
\text { hydromagmatic } \\
\text { explosive eruption }\end{array}$ & $1-3$ & $1-10 \mathrm{~km}$ & $\begin{array}{l}\text { Lava flows, ash } \\
\text { fall, gases, } \\
\text { blockandash, } \\
\text { PDC }\end{array}$ & $\begin{array}{l}5-10 \mathrm{~km} \text {, } \\
\text { longer } \\
\text { downstream }\end{array}$ \\
\hline C1 & High-deep (>500 m) & - & - & - & - \\
\hline $\mathrm{C} 2$ & $\begin{array}{l}\text { Medium-deep } \\
(500-\approx 200 \text { m. deep })\end{array}$ & - & - & $\begin{array}{l}\text { Water acidifying, } \\
\text { lava balloons, } \\
\text { large bubbles }\end{array}$ & $1-2 \mathrm{~km}$ \\
\hline $\mathrm{C} 3$ & Surtseyan $(<200 \mathrm{~m})$ & $1-3$ & $1-5 \mathrm{~km}$ & $\begin{array}{l}\text { lava flows, ash } \\
\text { fall, gases, surges }\end{array}$ & $1-2 \mathrm{~km}$ \\
\hline
\end{tabular}




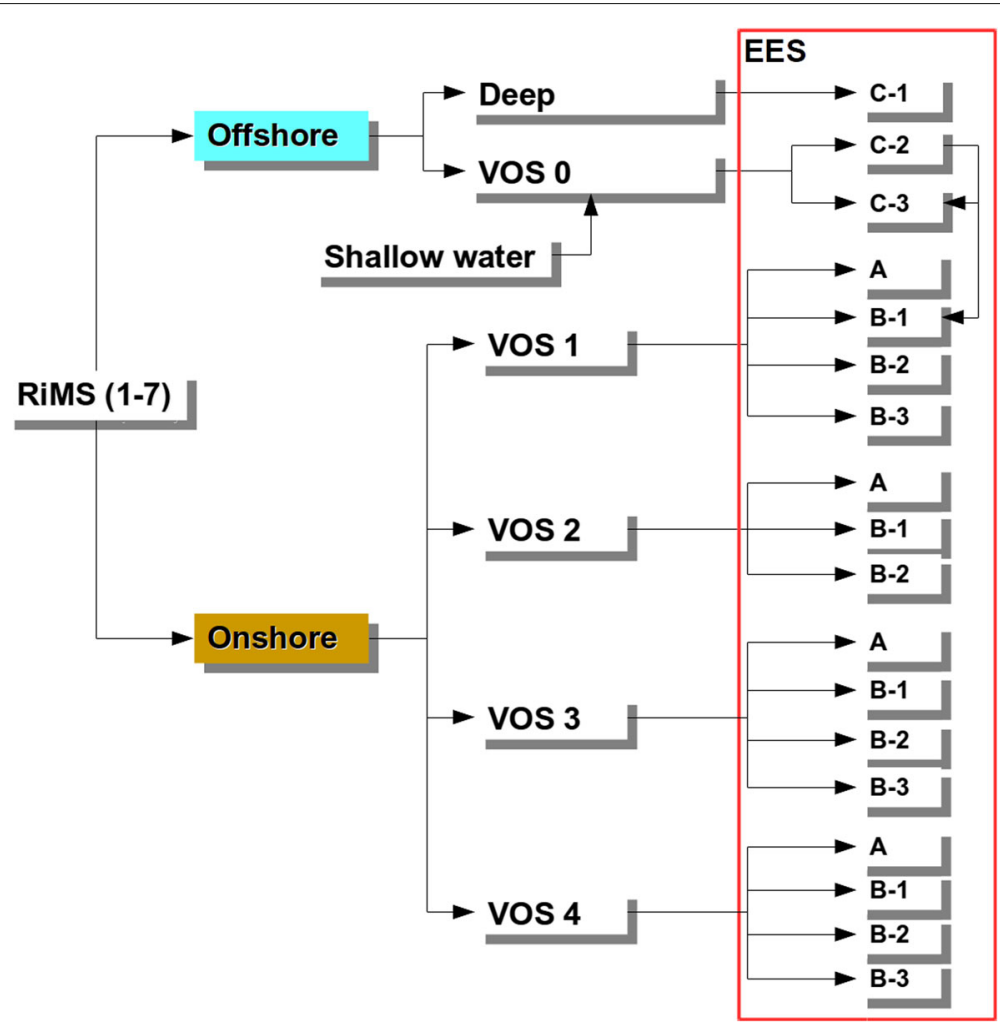

Fig. 5 Expected Eruptive Scenarios for La Palma Island according to the RiMS. The arrows between C2-C3 and B1 EESes highlight the possibility of an eruptive process migrates from offshore to onshore and changing its eruptive style. See text for more detailed information about EES

pyroclastic flow and pyroclastic surges must be added in the EES for B3 and C3. Other related natural hazards triggered by volcanic activity are not considered at this stage.

- Expected impact area: varies according to the EES but is also influenced by vent location. At medium or high elevations, the area must be increased downstream.

- Expected duration of superficial eruptive activity:: Activity may last between hours to days (Parfitt 2004), or months to years.

\section{Specific characteristics of the proposed EES: Onshore EES:}

1 A Type: Hawaiian style - magmatic eruptions.

- Main magma characteristics: High temperature, low viscosity and low gas content.

- VEI: 0-1, with column heights between 0 and 1 $\mathrm{km}$ (Newhall and Self 1982), although convective plumes can reach higher altitudes $(>8-10 \mathrm{~km})$ depending on the magma-production rate (Stothers et al. 1986; Kaminski et al. 2011).

- Predominant eruptive style: Lower volumes of tephra (Froggatt and Lowe 1990) emitted by lava fountains up to $500 \mathrm{~m}$ high, ballistically transported, deposited near the vent (Kereszturi and Németh 2012), and forming lava flows.

- Volcanic hazards: Mainly lava flows, ash fall close to the open vent and gas emissions.

- Expected impact area: Between 1 and $2 \mathrm{~km}$ from the vent, but at larger distances downstream.

- Comment: This specific EES was predominant during the Garafía and Taburiente volcano shield formation (Middlemost 1970; Carracedo et al. 2001) but in the recent eruptive history of La Palma has had low incidence.

2 B1 Type: Hawaiian/Strombolian style - magmatic effusive-explosive eruptions.

- Main magma characteristics: Lower temperature, higher viscosity and gas content than Type A.

- VEI: $1-2$, with column heights between 1 and 5 km (Newhall and Self 1982) and convective plumes at higher altitudes (Stothers et al. 1986; Kaminski et al. 2011).

- Predominant eruptive style: Frequent explosions forming large volumes of tephra 
mainly accumulated around the vent as solid scoria forming a cinder cone (Walker 1973; Houghton and Gonnermann 2008). Sometimes, the short time between explosions generates a sustained eruptive column (Parfitt 2004), but the level of explosivity can vary throughout the process and is conditioned by many factors (Houghton and Gonnermann 2008). This activity is also combined with lava emission phases.

- Expected volcanic hazards: Lava flows, gas emission, ash fall, block and ash flow.

- Expected impact area: Between 2 and $5 \mathrm{~km}$ from the vent, but at greater distances in valleys downstream.

- Comment: This type of volcanic activity is the most common not only in La Palma but also in the Canary Islands in general. See also Afonso et al. (1974) and Carracedo et al. (1996).

3 B2 Type: Hawaiian/Strombolian style - magmatic explosive eruptions - associated with magma mixing/solid plugs. It is basically the same as B1 type but with the following variants:

- Eruptive style: The small volume of evolved magma and lack of shallow magma chambers (Johansen et al. 2005) are not sufficient to modify the eruptive style, although according to Andújar and Scaillet (2012) a slight increase in the seismic activity and the extrusion of solid plugs bodies could be expected.

- Comment: This type of activity is mainly located in the summit area of Cumbre Vieja (Carracedo et al. 2001) where new eruptions may follow the same upward path created by earlier eruptions (White and Schmincke 1999).

4 B3 Type: Hawaiian/Strombolian/Violent Strombolian style - hydromagmatic explosive eruptions.

- VEI: 1-3, with column heights between 1 and 10 $\mathrm{km}$.

- Eruptive style: this is modified as a result of magma-water interaction. This type of activity evolves over the whole process or along different vents where diverse eruptive styles may occur (White and Schmincke 1999). Violent explosions may occur caused by interaction with water, producing magma fragmentation and large volumes of tephra. In multiple-vent eruptions, high explosivity may occur, but only at some vents while at others remain with dynamics shown in B1-B2 eruptive styles.
- Expected volcanic hazards: Lava flows, gas emission, ash fall, , pyroclastic density currents including pyroclastic surges and block and ash flows.

- Expected impact area: Between 5 and $10 \mathrm{~km}$ from the explosive vent, but may extend further in valleys downstream.

- Comment: This type of activity in La Palma is mainly located near the coastline and/or at high altitudes (see Fig. 3, White and Schmincke (1999); Klügel et al. (1999, 2000)).

\section{Offshore EES:}

1 C1 Type: deep (>500 m) submarine eruption.

- Eruptive style: There is no visual effects on the sea surface making volcanic activity only perceptible on the monitoring network. The explosive expansion of magmatic volatiles and superheated seawater are suppressed by the high hydrostatic pressure (Cas 1992).

2 C2 Type: medium-deep (500- $\approx 200$ m. deep) submarine eruption.

- Eruptive style: There are changes in the color of the sea-water, lava balloons (large gas-filled cavity surrounded by a thin shell, floating on the sea surface and not very common, Kueppers et al. (2012); López et al. (2012)), and large sporadic bubbles.

- Expected volcanic hazards: Lava balloons (Kueppers et al. 2012), sea-water acidification due to gas emission.

- Expected impact area: Between 1 and $2 \mathrm{~km}$, but depend on the currents, wind direction, coastline morphology and other factors.

3 C3 Type: Surtseyan eruption (<200 m).

- VEI: 1-3, with column heights between 1 and 5 $\mathrm{km}$.

- Eruptive style: From C2 type (initial phase) to explosively ejected tephra jets (when lower hydrostatic pressure allows vapor generation) (Moore 1985), evolving to pyroclastic surges at shallow levels. The frequency of explosion varies and the lava fragmentation is higher than in A, B1 and B2 types (Walker 1973).

- Comment: This type may evolve to B1 when the vent area is isolated from the sea-water (see also, (Thorarinsson 1965; De la Nuez and Quesada 1999)). C3 type may evolve to C2-C1 when the original vent migrates to larger depth areas (Carracedo et al. 2012). 


\section{Step 2: Definition of spatial zoning approach and the use of a random model}

An important methodological approach of this work was the decision to consider a uniform VOA for the whole island and the use of a random model to distribute the InVs for lava and pyroclastic flow hazards. These decisions were based on two types of groups of factors:

- Geology and volcanology factors:

- Recent eruptions have taken place in former volcanic areas in the Canary Archipelago.

- The location of the deep magma plumbing system was unknown and the monitoring data available at that time (2013) did not clarify its location.

- We considered the injection model proposed by (De la Cruz-Reyna and Yokoyama 2011).

- Geography and crisis management factors:

- The study area is relatively small, $706 \mathrm{~km}^{2}$

- La Palma is a high-risk volcanic island.

- The possibility that the low probability areas highlighted by susceptibility methods might mislead decision makers when interpreting the hazard maps.

With regards to the geological and volcanological factors, in the Canary Island it is common to find that recent eruptions occur near past eruptive areas (Carracedo et al. 1990; Bartolini et al. 2013) or distributed over the whole island, as is the case on El Hierro (Carracedo et al. 2001; Becerril et al. 2013). The location of the deep magma plumbing system together with the injection model used may be critical in explaining this spatial variability in vent location. The location of the deep magma plumbing system is still undefined in La Palma, with various different proposals of models (Fig. 4) while the injection model considered here was the one used during the El Hierro volcanic crisis by our group (García et al. 2014).

As far as the second group of factors is concerned, we believe that the spatial probability of a new vent (susceptibility) based only on observed surface elements (volcanic cones, dikes, etc.) might not be useful on a local and detailed scale on small and high-risk volcanic islands, where there are people living within the VOA. In the Canary Islands susceptibility results typically show only small differences between the lowest and the highest probability values. This issue can be observed in recent eruptive susceptibility studies for the Canary Islands: 0.0016-0.0063 in El Hierro (Becerril et al. 2013) and 0.00155-0.00465 in Lanzarote (Bartolini et al. 2013) and might be aggravated when divergent colour schemes are used to represent such small differences in probabilities, providing strong visual contrasts for relatively similar probability values (Thompson et al. 2015). If only the higher susceptibility values are taken into consideration in hazard assessment, the lower susceptibility areas may be contemplated as being safe by Civil Protection authorities.

With these groups of factors, we assumed the possibility that an eruption might occur anywhere (VOA), even although the most recent activity had been located around the Cumbre Vieja Unit (South), and we decided to use a random model to distribute InVs for lava and pyroclastic flow simulations. This approach would ensure that Civil Protection had a comprehensive view of the expected volcanic activity over the whole island, thus allowing them to design a variety of mitigation strategies in line with the proposed VOS and RiMS.

In the VOS zoning (Fig. 6), hydro-magmatic activity distribution was taken into account, considering the critical depth for magma fragmentation and the increase of explosivity produced as a result of the interaction between the magma and water. In line with these defining factors, we finally mapped 5 VOS's distributed over horizontal strips two located close to the sea (1-2) one at the top of the island (4) and one in the middle (3), reflecting EES characteristics.

As has been explained, the RiMS are directly related to the concept of the hazard map as an official printable document and define specific operational areas. In the case of La Palma, we defined 7 RiMS based on geographical and administrative factors in such a way that in the printed final hazard maps all the main areas of the island were represented. For example, RiMS b highlights the Aridane Valley (Fig. 6), an important area located in the southwestern part of the island. Nevertheless, the morphology of La Palma might mean that small differences in vent location generate different eruptive scenarios. It should be noted that although the 7 RiMS here have the same type of EES tree, this is not necessarily the case for other volcanic areas.

\section{Step 3: Constructing the volcanic hazard maps}

As was previously mentioned, the VOS is used as a key to organize the distribution of the random InVs, which vary in density according to the type of hazard and the hazard model used. To calculate the InVs, we designed a random function implemented in a Python script that considers the area (VOS), the minimum distance between vents, and the type of hazard. Figure 7 shows the InV random distribution for lava flows, pyroclastic flows and ash fall in VOS 4. The use of VOS allows for better management of the SHS and CHS as well as coverage of the VOA. We did not use Multiple Hazard Scenario (MHS) in the final hazard maps because we were representing thousands of independent eruptions, the opposite of what usually occurs in hazard maps developed for stratovolcanoes. 


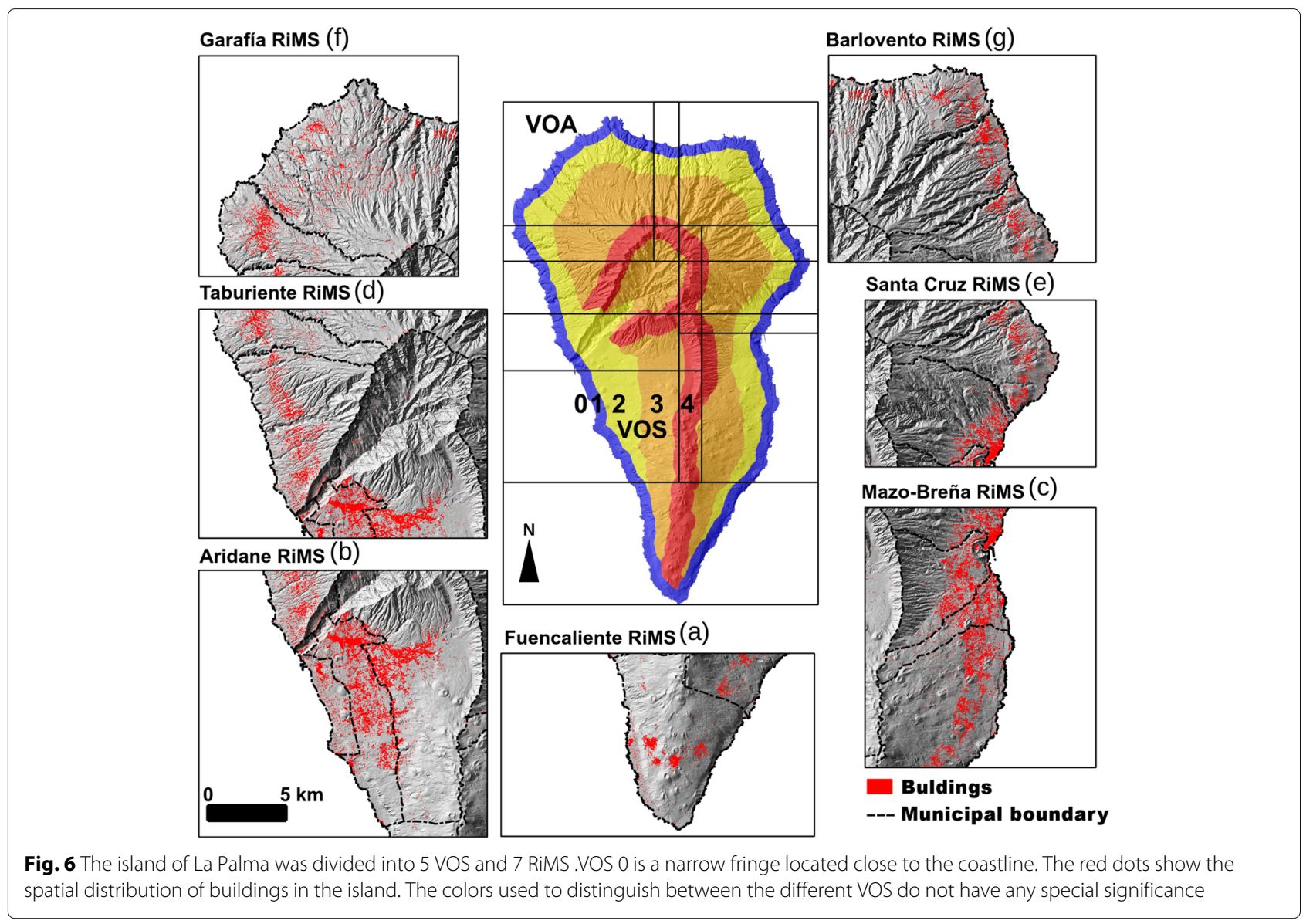

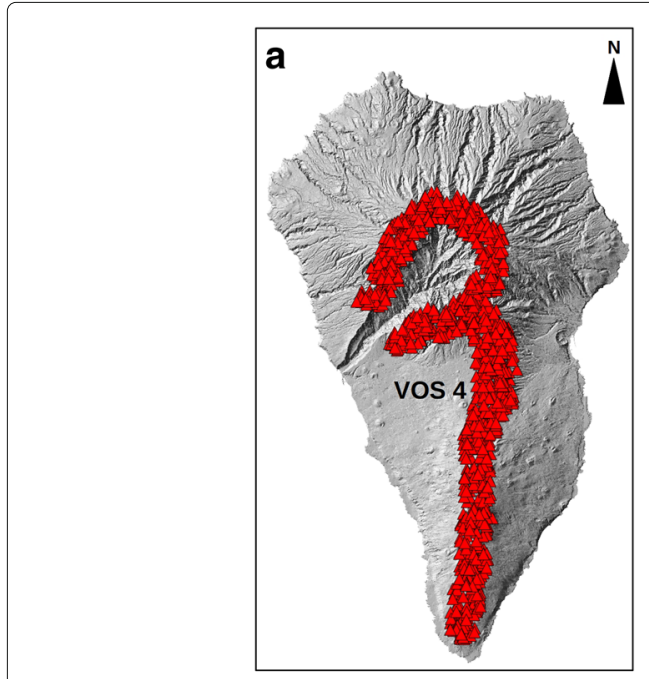

Input Vent
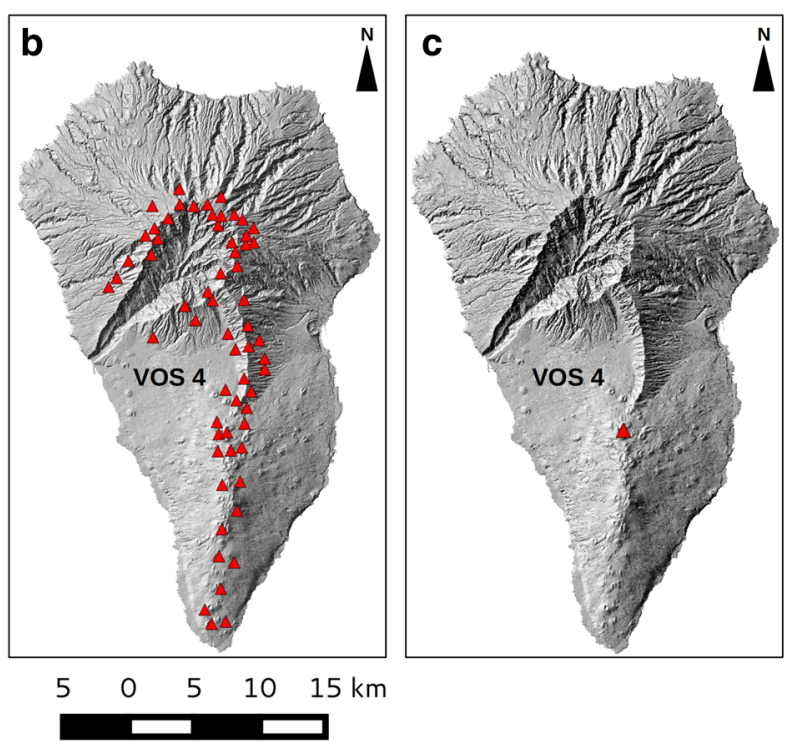

Fig. 7 For each volcanic hazard, the density of the random vents changes. From left to right, lava flow (a), pyroclastic flows (b) and ash fall (c) in VOS4 
It is important to underline that each volcanic hazard was treated in a different way methodologically according to the information that we considered most important for the authorities to know:

- Lava flow hazard maps are focused on detecting areas with the highest probability of being affected by this type of hazard.

- Pyroclastic flow hazard maps attempt to highlight the potential areas affected by this type of hazard (the different VOS).

- The ash fall hazard map shows the effects of changes in wind direction when the eruption lasts for several months, together with the possible influence of the various different climate situations commonly present in the Canary Islands.

Figure 8 shows the distribution of InVs (A) on each VOS for lava flow hazard (B). The marked geomorphological contrast between the northern and southern areas of the island is to be seen in the lava flow simulations. The well developed drainage network in the northern part of La Palma channels the lava flows while in the southern area the lava flows occupy a wider area. The parameters used in the simulations are shown in Table 3:

- A Critical Depth factor $(\delta)$, if the height of the lava flow is lower than $\mathrm{d}$, then the lava flow stops.

- The dispersion value $\left(d_{l}\right)$, allows the original InV to be moved at random around a defined radius.
- Maximum flow length $1_{\max }$, maximum distance reached by lava flows. In this work the coastline is the limit.

- Total number of iterations.

Figure 9 shows the distribution of InVs (A) in each VOS for pyroclastic flows (B). Given the limited existing information on pyroclastic flow parameters, we applied the parameters proposed by Toyos et al. (2007) and Kaye et al. (2009). Here, the most important question was to show that the same type of activity might produce different impact zones as a result of geomorphological variations. The results of the simulations can be expressed by deposit thickness $(m)$, flow velocity $(\mathrm{m} / \mathrm{s})$ or by dynamic pressure (Kpa) (Valentine 1998; Nunziante et al. 2003; Spence et al. 2007). In this work, we decided to normalize the data (deposit thickness) given the unknown volumes of pyroclastic flows, an approach designed to simplify scale representation. The parameters used in the simulations are shown in Table 4:

- The Heim coefficient $(\phi)$, represents the resistance due to friction (Malin and Sheridan 1982), using the guidelines established by Toyos et al. (2007) and Kaye et al. (2009), $20^{\circ}$ and $18^{\circ}$ were estimated for a B3 EES.

- The altitude above the vent or drop in height $\left(h_{c}\right)$, was the same value over all the simulations, 100 meters, to compare the effects produced by the topography.

In the case of an ash-fallout hazard, only one InV located at the summit area of Cumbre Vieja was used
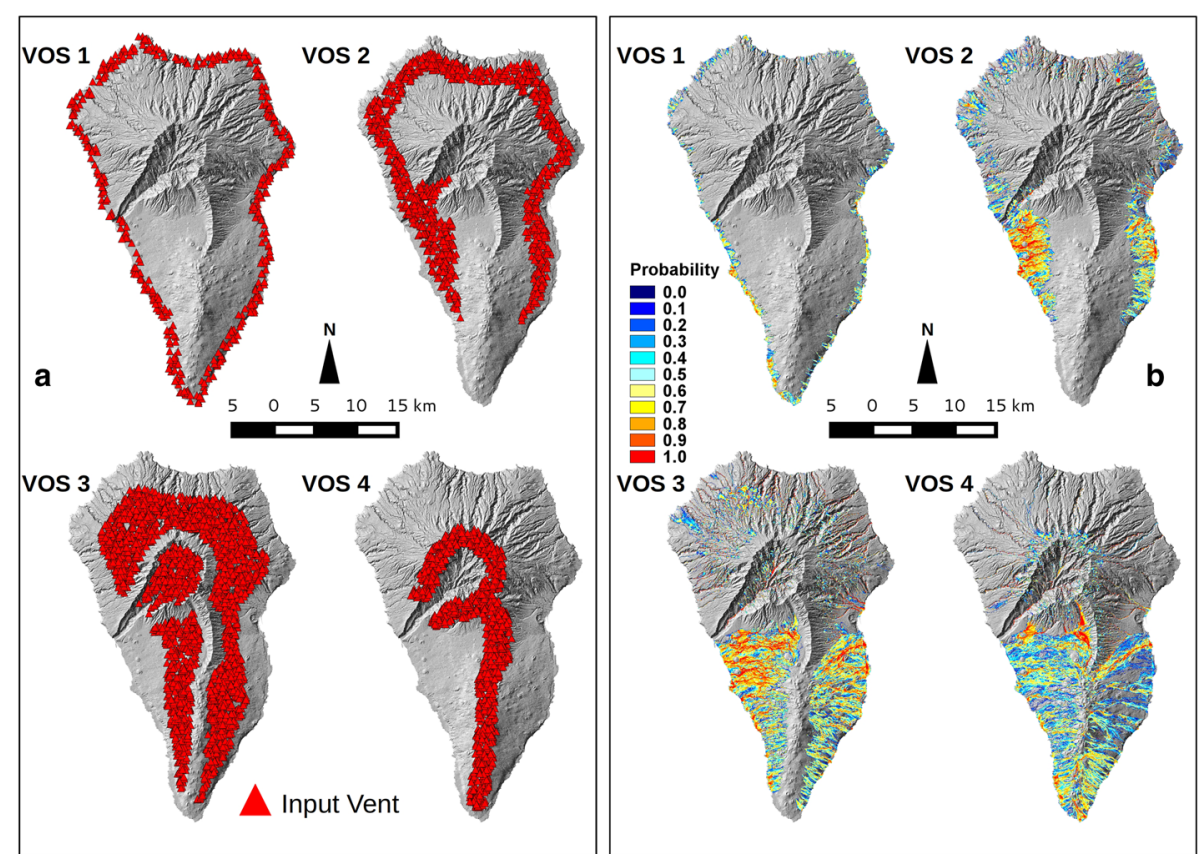

Fig. 8 Lava flow hazard (b) and InVs random distribution (a) in VOS 1-4 and EES A-B1-B2 (see Additional file 1 for more details). A normalized method has been used to scale the data, representing the probability that a cell will be affected by a lava flow 
Table 3 Lava flow parameters

\begin{tabular}{llll}
\hline RiMS & Geomorphology & $\delta$ (meters) & $d_{l}$ (meters) \\
\hline $\mathrm{e}, \mathrm{d}, \mathrm{f}, \mathrm{g}$ & Deep ravines & 3.0 & 10 \\
Northern half of $\mathrm{b}$ and $\mathrm{c}$ & Moderate slope & 2.5 & 30 \\
a, and Southern half of $\mathrm{b}$ and c & Steep slope & 2.0 & 40 \\
\hline
\end{tabular}

The high resolution of the DEM and the contrasted geomorphology made necessary to change $\delta$ and $d_{\text {, parameters }}$

(Fig. 10). Two approaches were applied in order to show the expected behavior of the ash fallout hazard. The first approach factors in the frequent weather changes (Fig. 10b) in such a way that the final hazard map shows the ash-fallout dispersion using a one-month timewindow (Fig. 10a). In the second, the four climate types of the Canary Islands were taken into consideration (Marzol and Máyer Suárez 2012), here named as follows:

- Trade winds or Alisios

- North Atlantic roughs or low pressure zones

- Tropical Atlantic roughs or low pressure zones

- Dust plumes from the Sahara or Calima

Instead of using statistical data, this approach relies on data collected over five days with one climate type ascribed to each day defined by its correlation with the climate-type features. The final hazard map shows the ash-fallout dispersion using a one-day time window. In both cases, the wind data column was compiled using radiosonde data collected twice daily from the Atmospheric Sounding Station in Güimar $\left(28.321^{\circ} \mathrm{N}\right.$, $16.381^{\circ} \mathrm{W}, 105 \mathrm{~m}$ a.s.l.). The parameters used in the simulations are shown in Table 5:

- Erupted Volume was estimated according to Mastin et al. (2009), assigning a value of $0.01 \mathrm{~km} 3$ for medium size basaltic eruptions.

- Column Height

- Average Particle Size is a critical parameter to estimate the terminal velocity of an airborne particle. The particle size is conditioned by the eruptive dynamic, so to develop the hazard map the following EES were considered: A and B1; B2; AND B3.

- Column Shape $(A)$ parameter depends on the type of particles considered.

- Standard Deviation

\section{Accompanying report}

Part of the information used in this manuscript was taken directly from the report developed for Civil Protection. We divided the report into four sections that addressed different important questions.

In the first section, we described the most important terms used in volcanic hazard and risk assessment and how we understood them. This was important given the complex contextual situation of communication between Civil Protection and research groups still present in the Canary Islands (Marrero et al. 2015; Ortiz et al. 2018).

The second section introduced the geological background of La Palma, focusing on certain specific issues such as responses to the most important questions usually
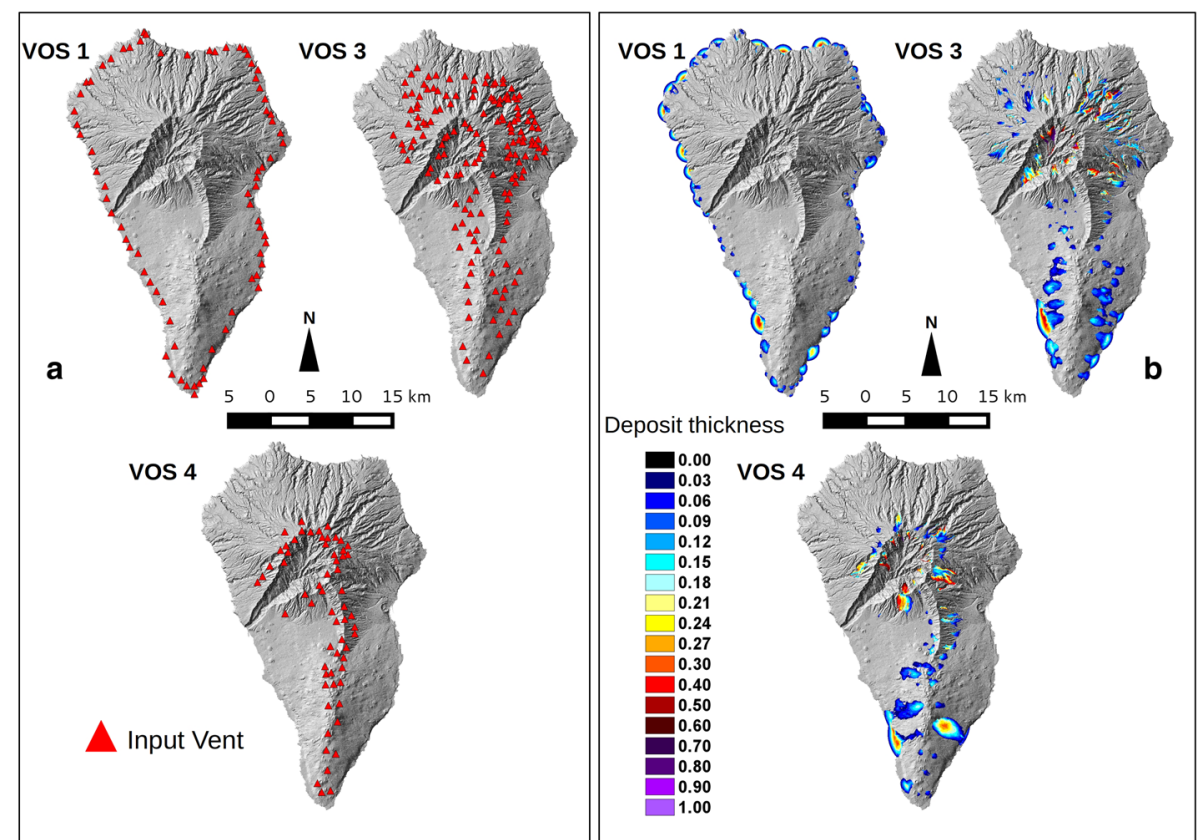

Fig. 9 Pyroclastic flow hazard (b) and InV random distribution (a) in VOS 1, 3, 4 and EES B3 (see Additional file 1 for more details). The scale represents the deposit thickness in relative values 
Table 4 Energy Cone parameters

\begin{tabular}{lll}
\hline VOS & $h_{c}$ (meters) & $\phi$ (degrees) \\
\hline 1,3 and 4 & 100 & 18 \\
1,3 and 4 & 100 & 20 \\
\hline
\end{tabular}

asked by Civil Protection (where, how and when). We briefly presented the evolution of the island, addressing the evolved magmas and water interaction to explain the possibility of explosive eruptions in some areas of the island. Another issue addressed was submarine eruptions, because in 2011 the El Hierro unrest (López et al. 2012) was characterized by submarine activity that had not been foreseen in the first version of the PEVOLCA (volcanic emergency plan for the Canary Islands) (Carracedo et al. 2012; Marrero et al. 2015). We also considered the primary or secondary hazards triggered by volcanic activity, such as seismicity, landslides, tsunamis, lahars and gas emissions. These hazards are not usually taken into account by the general community or by Civil Protection in their emergency plans in the Canary Islands, but the El Hierro volcanic crisis made clear the need to address them (García et al. 2014). Finally, we explained the spatial zoning approach and the EES.

In the third section, we described the methodology followed to carry out the hazard assessment, adding the color schemes that should be used in a digital environment. The idea was to provide a simple explanation of numerical models, how they were used, and to outline some of the significant technical limitations.

In the fourth section, we made some recommendations for future work that should be carried out in order to understand and improve volcanic hazard and risk assessment in La Palma.

\section{Discussion}

Visually, there are no great differences to be observed between the hazard maps developed following the approach presented here and other similar types of maps in the Canary Islands, fundamentally because the same hazard models have been used as the basis for all the maps (Araña et al. 2000; Felpeto et al. 2001, 2007; Becerril et al. 2014). However, it is at the level of territorial management that the main differences are to be detected. For instance,

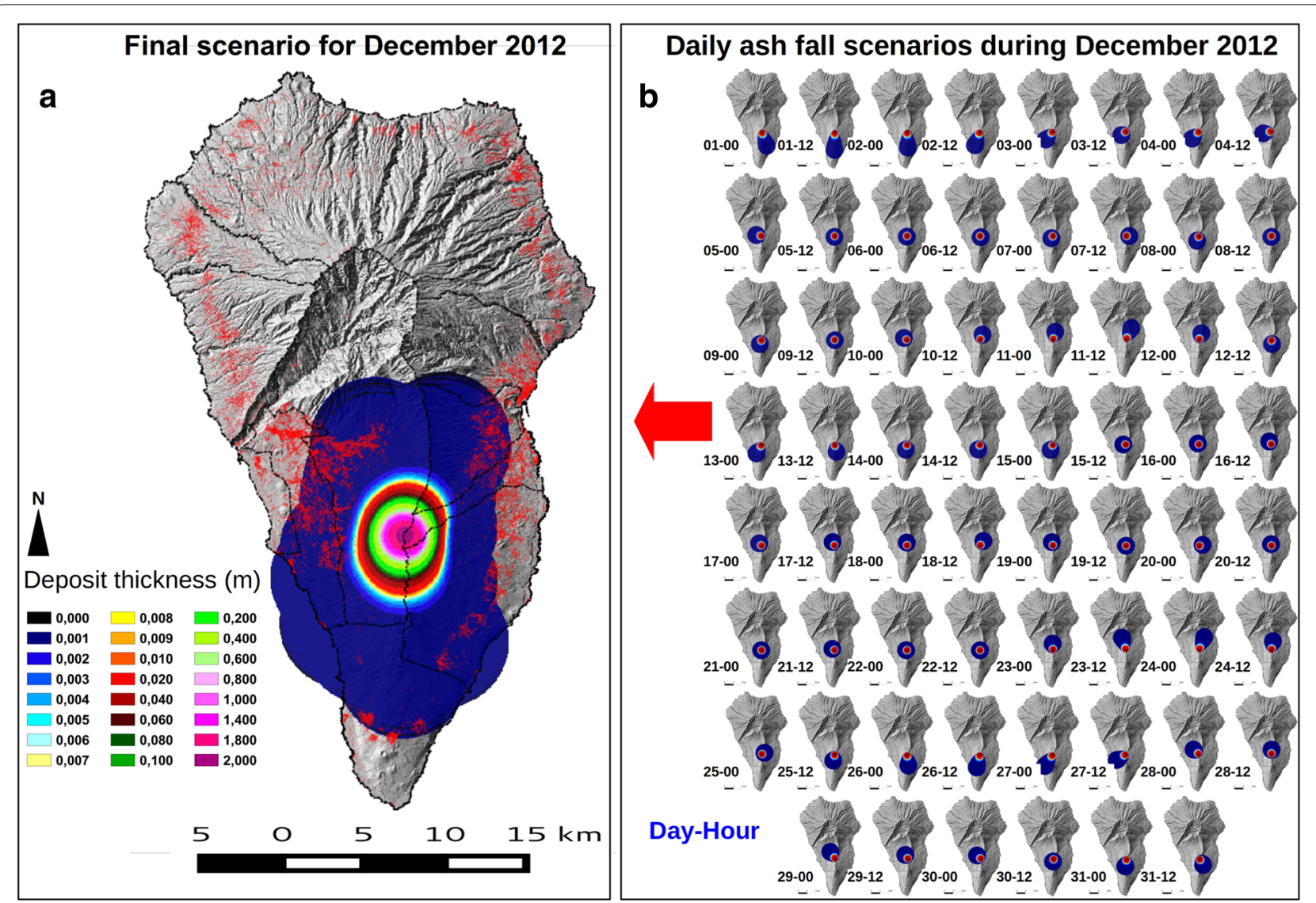

Fig. 10 Ash-fall hazard map. The parameter values used in the ash fallout model were conservative, trying to show the local impact. Figure $\mathbf{b}$ represent a daily ash fall scenario $(0$ and $12 \mathrm{~h})$, while Figure a represents the accumulated ash fall during one month time-window. The EES were grouped in A-B1, B1-B2 and B3 (see Additional file 1 for more details) 
Table 5 Ash fall parameters

\begin{tabular}{llllll}
\hline EES & Volume $(\mathrm{km} 3)$ & Column H. $(\mathrm{m})$ & Column F. & P.A.Size $(\phi)$ & Deviation \\
\hline A, B1 & 0.01 & 200 & 20 & -2 & 0.3 \\
B2 & 0.01 & 2000 & 20 & -1.5 & 0.5 \\
B3 & 0.01 & 5000 & 20 & -1.0 & 1.0 \\
\hline
\end{tabular}

in the case of Tenerife, a homogeneous square was used to divide up the whole of the island to make the detailedscale hazard maps (see, Hoyuela Jayo et al. (2007)). This technique gives an incomplete picture of some important geographic areas (RiMS) offering only a partial view that is complicated to interpret and manage in the development of mitigation strategies. In our approach, the division of $\mathrm{La}$ Palma into RiMS permits highlighting of various valleys and other geographic areas (see Fig. 6).

Another important question is the use of MHS (represented as qualitative hazard maps) for long-term planning in monogenetic volcanic fields, an approach used in both Tenerife (Hoyuela Jayo et al. 2007) and El Hierro (Becerril et al. 2014) hazard maps. This kind of hazard map represents the sum or combination of multiple vents instead of one. The location of these vents is critical to the final result. Any small variation in the location of $\mathrm{InV}$ will modify the final hazard map since higher and lower hazard values are highly conditioned by the InV locations. It should also be noted that lower probability is not synonymous with zero probability. This kind of map may mislead decision-makers in their risk assessment, in the same way as susceptibility maps, in that they may only focus the decision-makers' attention on specific areas where eruptions might take place, leading them to ignore the low probability areas (Thompson et al. 2015). In our approach, we kept each type of hazard separate from the rest and we tried to cover the VOA as much as possible with highdensity InV distribution, in line with the type of hazard modeled. To avoid excessive information, we distributed the InV over different VOS, all of which are easy to manage or print. The result is not one volcanic hazard map but rather several that consider the RiMS, VOS and volcanic scenarios defined previously, since the main aim is to show the expected volcanic hazards according to the proposed $E E S$, rather than to indicate where the next eruption is expected to occur.

At the same time, our approach can be used for shortterm management. During the El Hierro volcanic crisis, it was evident that it would prove extremely difficult to forecast the emplacement of a possible new vent on such a small island. Only valleys or important geographic areas were highlighted even when the maximum level of activity was reached (García et al. 2014). In such situations, our approach offers a global view and how a valley may be affected depending on where the vent is located, allowing Civil Protection to adopt various different emergency strategies.

\section{Limitations}

In hazard assessment, levels of uncertainty are influenced by multiple factors. Thus, a good understanding of volcanic activity, hazard models and the data used is needed to obtain the best possible results. Some of these factors may be grouped in the following ways: the frequency of eruptions together with our capacity to analyze, recognize and reconstruct past eruptive history (Marzocchi et al. 2012), the data accuracy (DEM resolution, scale used, etc., (Stevens et al. 2003)) and the characteristics of the hazard models (physical model, algorithms, input parameters, etc., (Renschler 2005)). In other words, the final volcanic hazard information must be used with great caution.

Our methodology was specifically designed for Civil Protection professionals as a tool to improve their understanding of volcanic activity and their capacity to design mitigation strategies. In the Canary Islands, there are still some pending problems related to volcanic crisis management that complicate this process (see, Marrero et al. (2015); Ortiz et al. (2018)). The methodology was also designed to be used in small and high-risk monogenetic volcanic fields where people live within the VOA. We applied a random model to distribute the $\mathrm{InV}$ for lava and pyroclastic flow simulations. It is important to underline that this approach overestimates the areas that may be affected by such volcanic hazards. We also considered very low probability areas within our hazard assessment although the volcanic activity in the last $0.1 \mathrm{Ma}$ has been located in the southern part of the island. The volcanic hazard assessment can also be considered separately from the spatial zoning approach, meaning that the hazard maps presented here do not represent hazard maps based purely on volcanology and geology factors. Approaches and methods have been combined to develop a more complete tool to be used in small and high-risk monogenetic volcanic fields before, during and after a volcanic crisis. We should also underline that this work was developed without the desirable interaction with Civil Protection, meaning that some aspects are still to be tested.

In October 2017, there was an important volcanotectonic swarm in La Palma (López et al. 2018) with over 300 events detected mostly beneath Cumbre Vieja. This new data may give weight to the $C$ model represented in Fig. 4 (Galipp et al. 2006), supporting the idea that the northern area would not have needed specific hazard assessment because the probability of an eruption there is low. Nevertheless, the present work was designed as a technical document for Civil Protection professionals who should be afforded an overall vision of the expected volcanic activity, at least in places such as La Palma. 


\section{Some i mportant issues}

Given the lack of interaction with Civil Protection during the development of this research, we cannot talk in as much detail about the lessons learned as we would like. Nevertheless, we have received positive feedback from some experts (researchers and technicians from Civil Protection) about how the volcanic hazard maps were understood and received. It should be noted that the present hazard maps were never socialized or issued to the general public, although they were available for some years albeit in a low-profile situation on the Web Map Server of the Canary Autonomous Government.

The time available to roll out this research was too limited (only 6 months), restricting the opportunity to interact with Civil Protection (after the El Hierro Eruption, the need for volcanic hazard maps for the other islands in the Canary Archipelago became of utmost importance). Civil Protection also had limited human resources, and although the volcanic hazard was considered to be of importance, it was not the only hazard on their daily agenda. We fully understand that the development of volcanic hazard maps represents a significant challenge and that interaction with the Civil Protection is of the utmost importance and often a greater challenge than the hazard maps themselves. This interaction is especially critical in high-risk volcanic areas, where the decision making process starts as soon new volcanic unrest is detected.

Despite the poor results in terms of collaboration, we consider that the methodology may be of great use to other similar areas around the world, hence the documentation of our experience in this scientific article. During the process of writing the scientific article, we realized that some aspects could have been improved upon. For instance, a better combination of susceptibility and random methods might have improved the spatial distribution of InV. Another significant issue was that we did not contemplate how to represent the volcanic hazard maps for the general public's understanding where other visual approaches and simplification would have had to be deployed, beginning with the explanation of how a hazard map represents thousands of possible results of the deep volcanic system rather than just the impact of one volcano.

\section{Conclusions}

The aim of this research is to facilitate communication between scientists and local authorities, using hazard maps as a tool to explain possible future volcanic activity. Such information must be fully comprehensible and, at the same time, useful in the organization and design of mitigation strategies. The information in the maps is complemented with a clear and simplified report (from the perspective of terminology used, methodologies, etc.) that identifies the problems and makes a number of recommendations designed to facilitate the work of the authorities. However, there is a need for real collaboration between scientists and decision-makers when developing volcanic hazard maps. The collaboration too often depends upon the severity of the volcanic activity and once the unrest is over, it ceases to exist. To keep collaboration alive, it is important to conduct drills where scientific groups identify the possible outcomes of volcanic scenarios, to hold frequent meetings and to constantly interact while the hazard maps are under development (Marrero et al. 2015). However, in the Canary Islands this strategy was not easy to apply in 2013 although some significant advances have been accomplished since then (Ortiz et al. 2018).

It is important to note that nowadays it is common practice to upload to a Geographical Information System (GIS), where the colors, scales and other attributes of maps may be altered, making the physical hazard maps, in the form of a printed document, less important than they were before. This becomes critical in high-risk contexts where a more precise definition of volcanic hazard limits is needed in order to design mitigation strategies. In such contexts, decision-makers need to understand the spatial relationship between the volcanic hazards and human environments, making detailed scales a requirement; this is easier in a digital environment.

The spatial-zoning approach is critical when dealing with monogenetic volcanic fields. Here a combination of three spatial elements (the VOA, VOS and RiMS) was used to manage not only the hazard models and completed hazard maps but also for the organization of the EES into tree-like structures. This methodology was applied in La Palma (Canary Islands), where various different volcanic hazard maps for lava flows, pyroclastic flows, and ash fallout were constructed, each varying according to the onshore and offshore EES, together with 5 VOS, finally separated into 7 RiMS. As a second measure, a more complex approach should be adopted introducing the probabilities and the Event Tree, together with more elaborate scenarios, such as worst-case or multihazard scenarios (bad weather, landslides, tsunamis, etc.), in order to improve the public authorities' knowledge and understanding of the decision-making process involved.

\section{Additional file}

Additional file 1: Hazard maps. As commented before, a new hazard study is underway, meaning the hazard maps mentioned in this work are no longer available to the public. Here we provided the original version of the hazard maps only modifying the size of the image files. (PDF 75,858 kb)

\section{Acknowledgements}

We are especially grateful to Humberto José Gutiérrez García, Jefe de Servicio de Protección Civil y Atención de Emergencias on the Canary Archipelago Autonomous Government at that time, for his valuable help and support. 


\section{Authors' contributions}

All authors were involved in the conceptual design of the study, and in drafting and revising the manuscript, using the experience acquired in other volcanic crises and most especially during the El Hierro volcanic process. The team carried out field surveys on La Palma using their own instrumentation, data processing, scenario design and forecasting models. RO and AG were permanent members of the SC of the PEVOLCA and MB an invited member. $\mathrm{JM}$ and $\mathrm{AL}$ coordinated the writing of the present paper and the preparation of all the related materials. All the authors have read, reviewed and approved the final manuscript.

\section{Funding}

This research was funded by projects under the auspices of the Dirección General de Seguridad y Emergencia of the Canary Archipelago Autonomous Government (MAC EMERNET-11600020) in cooperation with the Azores (Portugal) and The Republic of Cape Verde, and by the CSIC (2011-30E070) and MINECO (CGL2011-28682-C02-01).

\section{Competing interests}

The authors declare that they have no competing interests.

\section{Author details}

${ }^{1}$ REPENSAR, Camino de Orellana, Quito, Ecuador. ${ }^{2}$ Institute IGEO, CSIC-UCM, J. Gutierrez Abascal, 2, Madrid, Spain. ${ }^{3}$ Lab. Astronomía, Geodesia y Cartografía, Universidad de Cádiz, Avda. Universidad de Cádiz, Cádiz, Spain. ${ }^{4}$ Dpet. Animal Biology, Edaphology and Geology, University of La Laguna, La Laguna, Spain.

Received: 24 October 2018 Accepted: 1 July 2019

Published online: 27 July 2019

\section{References}

Abdel-Monem A, Watkins N, Gast P. Potassium-argon ages, volcanic stratigraphy, and geomagnetic polarity history of the Canary Islands; Tenerife, La Palma and Hierro. Am J Sci. 1972;272(9):805-25. https://doi. org/10.2475/ajs.272.9.805.

Acosta J, Uchupi E, Muñoz A, Herranz P, Palomo C, Ballesteros M. Geologic evolution of the Canarian Islands of Lanzarote, Fuerteventura, Gran Canaria and La Gomera and comparison of landslides at these islands with those at Tenerife, La Palma and El Hierro. Mar Geophys Res. 2003;24(1-2):1-40. https://doi.org/10.1007/s11001-004-1513-3.

Acosta J, Uchupi E, Smith D, Muñoz A, Herranz P, Palomo C, Llanes P, Ballesteros M. Comparison of volcanic rifts on La Palma and El Hierro, Canary Islands and the Island of Hawaii. In: Clift P, Acosta J, editors. Geophysics of the Canary Islands, vol 24. Springer Netherlands; 2005. p. 59-90. https://doi.org/10.1007/1-4020-4352-X_3.

Afonso A, Aparicio A, Hernández-Pacheco A, Badiola ER. Morphology evolution of Tengeuía volcano area. Estudios Geológicos Teneguía. 1974;19-26. http://digital.csic.es/bitstream/10261/3085/1/TENEGUIA.PDF. Accessed 23 Aug 2013.

Ancochea E, Hernán F, Cendrero A, Cantagrel JM, Fúster JM, Ibarrola E, Coello J. Constructive and destructive episodes in the building of a young Oceanic Island, La Palma, Canary Islands, and genesis of the Caldera de Taburiente. J Volcanol Geotherm Res. 1994;60(3-4):243-62. https://doi.org/ 10.1016/0377-0273(94)90054-X.

Andújar J, Scaillet B. Relationships between pre-eruptive conditions and eruptive styles of phonolite-trachyte magmas. Lithos. 2012;152:122-31. https://doi.org/10.1016/j.lithos.2012.05.009.

Araña V. Comentarios sobre la erupción del Volcán Teneguía en 1971. Enseñanza de las Ciencias de la Tierra. 1999;7(3):262-6. http://www.raco. cat/index.php/ECT/article/download/88641/132557. Accessed 9 Aug 2013.

Araña V, Felpeto A, Astiz M, García A, Ortiz R, Abella R. Zonation of the main v olcanic hazards (lava flows and ash fall) in Tenerife, Canary Islands. A proposal for a surveillance network. J Volcanol Geotherm Res. 2000;103(1-4):377-91. https://doi.org/http://dx.doi.org/10.1016/S0377-0273(00)00232-8.

Aspinall W. Structured Elicitation of Expert Judgment for Probabilistic Hazard and Risk Assessment in Volcanic Eruptions. In: Mader M, Coles G, Connor B, editors. Statistics in Volcanology, Special Publications of IAVCEI, vol. 1. London: Geological Society; 2006. p. 34-66. http://www.cas.usf.edu/ cconnor/geolsoc/html/chapter2.pdf. Accessed 24 June 2006.
Astiz M, Tárraga M, Sánchez N. Curso Internacional de Volcanología y Geofísica Volcánica, Casa de los Volcanes, vol 7, Excmo. Cabildo Insular de Lanzarote. Servicio de Publicaciones. Lanzarote, chap Modelos estadísticos en volcanología. 2000;5:401-10. http://canterbury.royalcommission.govt. nz/documents-by-key/20120411.4087/\$file/SEl.GNS.0021E.pdf.

Bartolini S, Cappello A, Martí J, Del Negro C. QVAST: a new Quantum GIS plugin for estimating volcanic susceptibility. Nat Hazards Earth Syst Sci. 2013;13:3031-42. https://doi.org/10.5194/nhessd-1-3031-2013.

Bartolini S, Geyer A, Martí J, Pedrazzi D, Aguirre-Díaz G. Volcanic hazard on Deception Island (South Shetland Islands, Antarctica). J Volcanol Geotherm Res. 2014. https://doi.org/10.1016/j.jvolgeores.2014.08.009.

Becerril L, Cappello A, Galindo I, Neri M, Del Negro C. Spatial probability distribution of future volcanic eruptions at El Hierro Island (Canary Islands, Spain). J Volcanol Geotherm Res. 2013;257:21-30. https://doi.org/10.1016/ j.jvolgeores.2013.03.005.

Becerril L, Bartolini S, Sobradelo R, Martí J, Morales J, Galindo I. Long-term volcanic hazard assessment on El Hierro (Canary Islands). Nat Hazards Earth Syst Sci Discuss. 2014;2:1799-835. https://doi.org/10.5194/nhessd-2-17992014.

Bevilacqua A, Isaia R, Neri A, Vitale S, Aspinall WP, Bisson M, Flandoli F, Baxter PJ, Bertagnini A, Esposti Ongaro T, et al. Quantifying volcanic hazard at Campi Flegrei caldera (Italy) with uncertainty assessment: I. Vent opening maps. J Geophys Res Solid Earth. 2015. https://doi.org/10.1002/ 2014JB011775.

Burt M, Wadge G, Curnow R. An objective method for mapping hazardous flow deposits from the stratigraphic record of stratovolcanoes: a case example from Montagne Peleè. Bull Volcanol. 2001;63(2-3):98-111. https:// doi.org/10.1007/s004450100128.

Camacho AG, Fernández J, González PJ, Rundle JB, Prieto JF, Arjona A. Structural results for La Palma island using 3-D gravity inversion. J Geophys Res Solid Earth 114(B5). 2009;B05:411. https://doi.org/10.1029/ 2008JB005628.

Cappello A, Neri M, Acocella V, Gallo G, Vicari A, Del Negro C. Spatial vent opening probability map of Etna volcano (Sicily, Italy). Bull Volcanol. 2012;74:2083-94. https://doi.org/10.1007/s00445-012-0647-4.

Carracedo J, Day S, Guillou H, Roríguez-Badiola E, Canas J, Pérez-Torrado FJ. Hotspot volcanism close to a passive continental margin: the Canary Islands. Geol Mag. 1998;135:591-604. http://journals.cambridge.org/ article_S0016756898001447. Accessed 4 June 2013.

Carracedo JC, Rodríguez-Badiola E, Soler V. Aspectos volcanológicos y estructurales. Evolución petrológica e implicaciones en riesgo volcánico de la erupción de 1730 en Lanzarote. Islas Canarias. Estudios Geológicos. 1990;46(1-2):25-55. http://digital.csic.es/handle/10261/23481. Accessed 14 Sept 2013.

Carracedo JC, Day S, Guillou H, Rodríguez Badiola E. The 1677 eruption of La P alma, Canary Islands. Estudios Geológicos. 1996;52(3-4):103-14. http:// estudiosgeol.revistas.csic.es/index.php/estudiosgeol/article/viewArticle/ 258. Accessed 24 Sep 2014

Carracedo JC, Day SJ, Guillou H, Pérez Torrado FJ. Giant Quaternary landslides in the evolution of La Palma and El Hierro, Canary Islands. J Volcanol Geothermal Res. 1999;94(1-4):169-90. https://doi.org/10.1016/S03770273(99)00102-X.

Carracedo JC, Rodríguez-Badiola ER, Guillou H, de la Nuez J, Pérez-Torrado FJ. Geology and volcanology of La Palma and El Hierro, Western Canaries. Estudios Geológicos. 2001;57(5-6):175-273. http://hdl.handle.net/10261/ 2343. Accessed 7 Sep 2001.

Carracedo JC, Pérez-Torrado FJ, Rodríguez-González A, Soler V, Fernández-Turiel JL, Troll VR, Wiesmaier S. The 2011 submarine volcanic eruption in El Hierro (Canary Islands). Geol Today. 2012;28(2):53-58. https://doi.org/10.1111/j.1365-2451.2012.00827.x.

Cas R. Submarine volcanism; eruption styles, products, and relevance to understanding the host-rock successions to volcanic-hosted massive sulfide deposits. Economic Geol. 1992;87(3):511-41. https://doi.org/10. 2113/gsecongeo.87.3.511.

Crandell DR, Mullineaux DR. Potential hazards from future eruptions of Mount St. Helens volcano, Washington, geological survey bulletin, edn 1383. Washington: United States Goverment Printing Office; 1978. http://pubs. usgs.gov/bul/1383c/report.pdf. Accessed 6 July 2015.

Crisci GM, Rongo R, Di Gregorio S, Spataro W. The simulation model SCIARA: the 1991 and 2001 lava flows at Mount Etna. J Volcanol Geotherm Res. 2004;132(2):253-67. https://doi.org/10.1016/S0377-0273(03)00349-4. 
Day S, Carracedo J, Guillou H, Gravestock P. Recent structural evolution of the Cumbre Vieja volcano, La Palma, Canary Islands: volcanic rift zone reconfiguration as a precursor to volcano flank instability? J Volcanol Geotherm Res. 1999;94(1-4):135-67. https://doi.org/10.1016/S03770273(99)00101-8.

De la Cruz-Reyna S, Tilling R. Scientific and public responses to the ongoing volcanic crisis at PopocatépetI Volcano, Mexico: Importance of an effective hazards-warning system. J Volcanol Geothermal Res. 2008;170(1):121-34. https://doi.org/10.1016/j.jvolgeores.2007.09.002.

De la Cruz-Reyna S, Yokoyama I. A geophysical characterization of monogenetic volcanism. Geofísica Int. 2011;50:465-84. http://www.scielo.org.mx/scielo. php?script=sci_arttext\&pid=S0016-71692011000400008\&nrm=iso. Accessed 16 Sept 2013

De la Nuez J, Quesada M. El edificio hidromagmático de Montaña Goteras en la Palma (Islas Canarias). Boletín Geológico y Minero. 1999;110(1):19-24. http://www.igme.es/internet/sistemas_infor/BoletinGeoPDF/boletin \%20110\%20fasciculo\%201.pdf. Accessed 27 Sep 2013.

Doyle E, Johnston D. Science advice for critical decision-making. In: Paton D, Violanti J, editors. Working in high risk environments: developing sustained resilience, Charles C Thomas, Springfield, Illinois, USA, chap 5; 2011. p. 69-92. http://canterbury.royalcommision.govt.nz/documents-by-key/ 20120411.4087/\$file/SEl.GNS.0021E.pdf.

Doyle EE, McClure J, Johnston DM, Paton D. Communicating likelihoods and probabilities in forecasts of volcanic eruptions. J Volcanol Geotherm Res. 2014;272(0):1-15. https://doi.org/10.1016/j.jvolgeores.2013.12.006.

Felpeto A, Araña V, Ortiz R, Astiz M, García A. Assessment and Modelling of Lava Flow Hazard on Lanzarote (Canary Islands). Nat Hazards. 2001;23(2-3): 247-57. https://doi.org/10.1023/A:1011112330766.

Felpeto A, Martí J, Ortiz R. Automatic GIS-based system for volcanic hazard assessment. J Volcanol Geotherm Res. 2007;166(2):106-16. https://doi.org/ 10.1016/j.jvolgeores.2007.07.008.

Fisher RV, Schmincke HU. Submarine volcaniclastic rocks. In: Pyroclastic rocks, Geological Society of London, chap 10. Special Publications; 1984. p. 265-96. https://doi.org/10.1007/978-3-642-74864-6_10.

Folch A, Felpeto A. A coupled model for dispersal of tephra during sustained explosive eruptions. J Volcanol Geotherm Res. 2005;145(3):337-49. https:// doi.org/10.1016/j.jvolgeores.2005.01.010.

Folch A, Costa A, Macedonio G. FALL3D: A computational model for transport and deposition of volcanic ash. Comput Geosci. 2009;35(6):1334-42. https://doi.org/10.1016/j.cageo.2008.08.008.

Froggatt PC, Lowe DJ. A review of late Quaternary silicic and some other tephra formations from New Zealand: their stratigraphy, nomenclature, distribution, volume, and age. NZ J Geol Geophys. 1990;33:89-109. https:// doi.org/10.1080/00288306.1990.10427576.

Galipp K, Klügel A, Hansteen TH. Changing depths of magma fractionation and stagnation during the evolution of an oceanic island volcano: La Palma (Canary Islands). J Volcanol Geotherm Res. 2006;155(3):285-306. https://doi.org/10.1016/j.jvolgeores.2006.04.002.

García A, Fernández-Ros A, Berrocoso M, Marrero J, Prates G, De la Cruz-Reyna S, Ortiz R. Magma displacements under insular volcanic fields, applications to eruption forecasting: El Hierro, Canary Islands, 2011-2013. Geophys J Int. 2014;196(1):1-13. https://doi.org/10.1093/gji/ggt505.

GRAFCAN. Cartográfica de Canarias S.A. 2009. http://www.grafcan.com. Accessed 24 Sept 2012.

Guillou H, Carracedo J, Duncan R. K-Ar, 40Ar-39Ar ages and magnetostratigraphy of Brunhes and Matuyama lava sequences from La Palma Island. J Volcanol Geotherm Res. 2001;106(3-4):175-94. https://doi. org/10.1016/S0377-0273(00)00294-8.

Hernández-Pacheco A. Sobre una posible erupción en 1793 en la isla de El Hierro (Canarias). Estudios Geológicos. 1982;38(1-2):15-26. http://dialnet. unirioja.es/servlet/articulo?codigo=2757224. Accessed 23 Feb 2013.

Houghton B, Gonnermann H. Basaltic explosive volcanism: constraints from deposits and models. Chemie der Erde-Geochemistry. 2008;68(2):117-40. https://doi.org/10.1016/j.chemer.2008.04.002.

Hoyuela Jayo JA, Gomez Fernandez F, Martínez Alegría R. Plan Territorial Espacial de Ordenación para la Prevención de riesgos. techreport. Cabildo de Tenerife; 2007. http://www.tenerife.es/planes/PTEOPrevRiesgos/ adjuntos/PINF_Anexo03.pdf. Accessed 1 June 2015.

Hsü K. Catastrophic debris streams (sturzstroms) generated by rockfalls. Geol Soc Am Bull. 1975;86(1):129-40. https://doi.org/10.1130/00167606(1975)86<129:CDSSGB>2.0.CO;2.
Johansen TS, Hauff F, Hoernle K, Klügel A, Kokfelt T. Basanite to phonolite differentiation within 1550-1750 yr: U-Th-Ra isotopic evidence from the A.D. 1585 eruption on La Palma, Canary Islands. Geology. 2005;33(11): 897-900. https://doi.org/10.1130/\&ZeroWidthSpace;G21663.1.

Kaminski E, Chenet AL, Jaupart C, Courtillot V. Rise of volcanic plumes to the stratosphere aided by penetrative convection above large lava flows. Earth Planet Sci Lett. 2011;301:171-8. https://doi.org/10.1016/j.epsl.2010.10.037.

Kaye G, Cole J, King A, Johnston D. Comparison of risk from pyroclastic density current hazards to critical infrastructure in Mammoth Lakes, California, USA, from a new Inyo craters rhyolite dike eruption versus a dacitic dome eruption on Mammoth Mountain. Nat Hazards. 2009;49(3): 541-63. https://doi.org/10.1007/s11069-009-9465-1.

Kereszturi G, Németh K. Monogenetic basaltic volcanoes: genetic classification, growth, geomorphology and degradation. In: Németh K, editor. Updates in Volcanology - New Advances in Understanding Volcanic Systems, Earth and Planetary Sciences, vol 2, InTech, chap 1; 2012. p. 3-89. https://doi.org/10.5772/51387.

Klügel A, Schmincke H, White J, Hoernle K. Chronology and volcanology of the 1949 multi-vent rift-zone eruption on La Palma (Canary Islands). J Volcanol Geotherm Res. 1999;94(1-4):267-82. https://doi.org/10.1016/ S0377-0273(99)00107-9.

Klügel A, Hoernle KA, Schmincke HU, White JD. The chemically zoned 1949 eruption on La Palma (Canary Islands): Petrologic evolution and magma supply dynamics of a rift zone eruption. J Geophys Res Solid Earth. 2000;105(B3):5997-6016. https://doi.org/10.1029/1999JB900334.

Klügel A, Hansteen TH, Galipp K. Magma storage and underplating beneath Cumbre Vieja volcano, La Palma (Canary Islands). Earth Planet Sci Lett. 2005;236(1):211-26. https://doi.org/10.1016/j.epsl.2005.04.006.

Kokelaar P. Magma-water interactions in subaqueous and emergent basaltic Bull Volcanol. 1986;48(5):275-89. https://doi.org/10.1007/bf01081756.

Kueppers U, Nichols AR, Zanon V, Potuzak M, Pacheco JM. Lava balloons-peculiar products of basaltic submarine eruptions. Bull Volcanol. 2012;74:1379-93. https://doi.org/10.1007/s00445-012-0597-X.

López C, Blanco MJ, Abella R, Brenes B, Rodríguez-Cabrera VM, Casas B, Cerdeña ID, Felpeto A, de Villalta F, del Fresno C, García O, García-Arias M, García-Cañada L, Gomis-Moreno A, González-Alonso E, Guzmán-Pérez J, Iribarren I, López-Díaz R, Luengo-Oroz N, Meletlidis S, Moreno M, Moure D, Pereda de Pablo J, Rodero C, Romero E, Sainz-Maza S, Sentre-Domingo M, Torres P, Trigo P, Villasante-Marcos V. Monitoring the volcanic unrest of El Hierro (Canary Islands) before the onset of the 2011-2012 submarine eruption. Geophys Res Lett 39:L13. 2012303. https:// doi.org/10.1029/2012GL051846.

López C, Villasante-Marcos V, Domínguez Cerdeña I, Lamolda H, Luengo-Oroz N, del Fresno C, Pereda J, Torres González PA, González-Alonso E, Fernández-García A, et al. On the origin of the 2017 seismovolcanic activity in la palma. In: EGU General Assembly Conference Abstrac ts, vol. 20; 2018. p. 7694. https://meetingorganizer.copernicus.org/ EGU2018/EGU2018-7694.pdf. Accessed 16 June 2019.

Macedonio G, Costa A, Folch A. Ash fallout scenarios at Vesuvius: numerical simulations and implications for hazard assessment. J Volcanol Geotherm Res. 2008;178(3):366-77. https://doi.org/10.1016/j.jvolgeores.2008.08.014.

Malin M, Sheridan M. Computer-assisted mapping of pyroclastic surges. Science. 1982;217(4560):637-40. https://doi.org/10.2307/1688912.

Marrero J, García A, Llinares A, De la Cruz-Reyna S, Ramos S, Ortiz R. Virtual Tools for volcanic crisis management, and evacuation decision support: Applications to El Chichón volcano (Chiapas, Mexico). Nat Hazards. 2013;68:955-80. https://doi.org/10.1007/s11069-013-0672-4.

Marrero J, García A, Llinares A, Berrocoso M, Ortiz R. Legal framework and scientific responsibilities during volcanic crises: the case of the El Hierro eruption (2011-2014). J Appl Volcan. 2015;4:13. https://doi.org/10.1186/ s13617-015-0028-8.

Martínez-Arevalo C, Mancillab FdL, Helffrichc G, García A. Seismic Evidence of a Regional Sublithospheric Low Velocity Layer beneath the Canary Islands. Tectonophysics. 2013;608:586-99. https://doi.org/10.1016/j.tecto.2013.08. 021.

Marzocchi W, Sandri L, Selva J. BET_EF: a probabilistic tool for long-and short-term eruption forecasting. Bull Volcanol. 2008;70(5):623-32. https:// doi.org/10.1007/s00445-007-0157-y.

Marzocchi W, Newhall C, Woo G. The scientific management of volcanic crises. J Volcanol Geotherm Res. 2012;247-248(0):181-9. https://doi.org/ 10.1016/j.jvolgeores.2012.08.016. 
Marzol MV, Máyer Suárez P. Algunas reflexiones acerca del clima de las Islas Canarias. Nimbus: Revista de climatología, meteorología y paisaje. 2012;29-30(29):399-416. http://dialnet.unirioja.es/descarga/articulo/ 4376863.pdf. Accessed 28 Nov 2013.

Mastin L, Guffanti M, Servranckx R, Webley P, Barsotti S, Dean K, Durant A, Ewert J, Neri A, Rose W, Schneider D, Siebert L, Stunder B, Swanson G, Tupper A, Volentik A, Waythomas C. A multidisciplinary effort to assign realistic source parameters to models of volcanic ash-cloud transport and dispersion during eruptions. J Volcanol Geotherm Res. 2009;186(1):10-21. https://doi.org/10.1016/j.jvolgeores.2009.01.008.

Mastin LG, Christiansen RL, Thornber C, Lowenstern J, Beeson M. What makes hydromagmatic eruptions violent? Some insights from the Keanakāko'i Ash, Kïlauea Volcano, Hawai'i. J Volcanol Geotherm Res. 2004;137(1):15-31. https://doi.org/10.1016/j.jvolgeores.2004.05.015.

McGuire W, Solana M, Kilburn C, Sanderson D. Improving communication during volcanic crises on small, vulnerable islands. J Volcanol Geotherm Res. 2009;183(1-2):63-75. https://doi.org/10.1016/j.jvolgeores.2009.02.019.

Middlemost E. San Miguel de La Palma - A volcanic island in section. Bull Volcanol. 1970;34(1):216-39. https://doi.org/10.1007/BF02597787.

Moore JG. Structure and eruptive mechanisms at Surtsey Volcano, Iceland. Geol Mag. 1985;122(06):649-61. https://doi.org/10.1017/S0016756800032052.

Mothes P, Espín P, Hall M, Vásconez F, Sierra A, Andrade D. Mapa regional de amenazas volcánicas potenciales del volcán cotopaxi, zona norte. Mapa de peligros, Instituto Geofísico. Escuela Politécnica Nacional. 2016a. https:// www.igepn.edu.ec/publicaciones-vulcanologia/mapas-de-peligros/19mapa-de-peligros-cotopaxi-norte. Accessed 19 Jan 2019.

Mothes P, Espín P, Hall M, Vásconez F, Sierra A, Andrade D. Mapa regional de amenazas volcánicas potenciales del volcán cotopaxi, zona sur. Mapa de peligros, Instituto Geofísico. Escuela Politécnica Nacional. 2016b. https:// www.igepn.edu.ec/publicaciones-vulcanologia/mapas-de-peligros/19mapa-de-peligros-cotopaxi-norte. Accessed 19 Jan 2019.

Németh K, Kereszturi G. Monogenetic volcanism: personal views and discussion. Int J Earth Sci. 2015;104(8):2131-46. https://doi.org/10.1007/ s00531-015-1243-6.

Newhall C, Hoblitt R. Constructing event trees for volcanic crises. Bull Volcanol. 2002;64(1):3-20. https://doi.org/10.1007/s004450100173.

Newhall C, Aramaki S, Barberi F, Blong R, Calvache M, Cheminee J, Punongbayan R, Siebe C, Simkin T, Sparks R, Tjetjep W. Professional conduct of scientists during volcanic crises. Bull Volcanol. 1999;60:323-34. https://doi.org/10.1007/PL00008908.

Newhall C, Costa F, Ratdomopurbo A, Venezky D, Widiwijayanti C, Win NTZ, Tan K, Fajiculay E. Wovodat-an online, growing library of worldwide volcanic unrest. J Volcanol Geotherm Res. 2017;345:184-199. https://doi. org/10.1016/j.jvolgeores.2017.08.003.

Newhall CG, Self S. The Volcanic Explosivity Index (VEI) an estimate of explosive magnitude for historical volcanism. J Geophys Res Oceans. 1982;87(C2):1231-8. https://doi.org/10.1029/JC087iC02p01231.

Nunziante L, Fraldi M, Lirer L, Petrosino P, Scotellaro S, Cicirelli C. Risk assessment of the impact of pyroclastic currents on the towns located around Vesuvio: a non-linear structural inverse analysis. Bull Volcanol. 2003;65(8):547-61. https://doi.org/10.1007/s00445-003-0282-1.

Ortiz R, Marrero JM, García A, Llinares A, Melo V. Risk management issues in tourist regions with explosive volcanism: The teide's 2004 unrest, canary islands. Ann Geophys. 2018;61:38. https://doi.org/10.4401/ag-7698.

Parfitt EA. A discussion of the mechanisms of explosive basaltic eruptions. J Volcanol Geotherm Res. 2004;134(1):77-107. https://doi.org/10.1016/j. jvolgeores.2004.01.002.

Parra E, Cepeda H. Volcanic hazard maps of the Nevado del Ruiz volcano, Colombia. J Volcanol Geotherm Res. 1990;42(1):117-27. https://doi.org/10. 1016/0377-0273(90)90073-O.

Pistolesi M, Cioni R, Bonadonna C, Elissondo M, Baumann V, Bertagnini A Chiari L, Gonzales R, Rosi M, Francalanci L. Complex dynamics of small-moderate volcanic events: the example of the 2011 rhyolitic Cordón Caulle eruption, Chile. Bull Volcanol. 2015;77(1):1-24. https://doi.org/10. 1007/s00445-014-0898-3.

Quesada M, Alonso J, De La Nuez J. Evolución submarino-subaérea del edificio hidromagmático de la Caldereta (La Palma, Canarias). In: II Congr. Geol. España; 1998. p. 377-86. https://books.google.com.ec/books?id= 3yG7qk_8JWoC\&printsec $=$ frontcover\&amp;hl=es\&source $=$ gbs ge summary $r \& c a d=0 \# v=0$ nepage\&q\&f=false. Accessed 27 Sept 2013.
Renschler CS. Scales and uncertainties in using models and GIS for volcano hazard prediction. J Volcanol Geotherm Res. 2005;139:73-87. https://doi. org/10.1016/j.jvolgeores.2004.06.016.

Romero C. Las manifestaciones volcánicas históricas del Archipiélago Canario. PhD thesis. Tenerife: Universidad de la Laguna, La Laguna; 1990. https:// doi.org/84-7756-219-9.

Scandone R, Giacomelli L, Speranza FF, Plastino W. Classification and quantification of volcanic eruptions. Bollettino di Geofisica Teorica ed Applicata. 2009;50(2):103-16. http://www2.ogs.trieste.it/bgta/provapage. php?id_articolo=456. Accessed 26 Sept 2013.

Scott WE. Volcanic-Hazards Zonation and Long-Term Forecasts. In: Tilling R, editor. A short Course in Geology, vol 1, Volcanic Hazards. Washington, D.C. American Geophysical Union. Wiley Online Library, chap 3; 1989. p. 25-49. https://doi.org/10.1029/SC001p0025.

Servicio Geológico Colombiano. Mapa de amenaza volcánica del volcán nevado del ruízescala 1:20 000. techreport. 2015. https://www2.sgc.gov.co/sgc/ volcanes/VolcanNevadoRuiz/Documents/Mapa_de_Amenaza-VNR_v32015.pdf.

Sheridan M, Malin M. Application of computer-assisted mapping to volcanic hazard evaluation of surge eruptions: Vulcano, Lipari, and Vesuvius. J Volcanol Geotherm Res. 1983;17(1):187-202. https://doi.org/10.1016/ 0377-0273(83)90067-7.

Singer B, Relle M, Hoffman K, Battle A, Laj C, Guillou H, Carracedo J. Ar/Ar ages from transitionally magnetized lavas on La Palma, Canary Islands, and the geomagnetic instability timescale. J Geophys Res. 2002;107(B11):2307. https://doi.org/10.1029/2001JB001613.

Spence R, Kelman I, Brown A, Toyos G, Purser D, Baxter P. Residential building and occupant vulnerability to pyroclastic density currents in explosive eruptions. Nat Hazards Earth Syst Sci. 2007;7(2):219-30. https:// doi.org/10.5194/nhess-7-219-2007.

Staudigel H, Feraud G, Giannerini G. The history of intrusive activity on the island of La Palma (Canary Islands). J Volcanol Geotherm Res. 1986;27(3-4): 299-322. https://doi.org/10.1016/0377-0273(86)90018-1.

Stevens N, Manville V, Heron D. The sensitivity of a volcanic flow model to digital elevation model accuracy: experiments with digitised map contours and interferometric SAR at Ruapehu and Taranaki volcanoes, New Zealand. J Volcanol Geotherm Res. 2003;119(1):89-105. https://doi. org/10.1016/S0377-0273(02)00307-4.

Stothers RB, Wolff JA, Self S, Rampino MR. Basaltic fissure eruptions, plume heights, and atmospheric aerosols. Geophys Res Lett. 1986;13(8):725-8. https://doi.org/10.1029/GL013i008p00725.

Thompson MA, Lindsay JM, Gaillard J. The influence of probabilistic volcanic hazard map properties on hazard communication. J Appl Volcanol. 2015;4(1):6. https://doi.org/10.1186/s13617-015-0023-0.

Thorarinsson S. The Surtsey eruption course of events and the development of the new island. In: Committee TSR, editor. Surtsey Research Progress Report, vol. 1. Iceland: The Surtsey Research Society, Reykjavik; 1965. p. 51-56. http://www.surtsey.is/SRS_publ/1965-I/1965_I_5_01.pdf. Accessed 11 Oct 2013

Tomsen E, Lindsay J, Gahegan M, Wilson TM, Blake DM. Evacuation planning in the Auckland Volcanic Field, New Zealand: a spatio-temporal approach for emergency management and transportation network decisions. J Appl Volcanol. 2014;3:1:22. https://doi.org/10.1186/2191-5040-3-6.

Toyos G, Cole P, Felpeto A, Marti J. A GIS-based methodology for hazard mapping of small volume pyroclastic density currents. Nat Hazards. 2007;41(1):99-112. https://doi.org/10.1007/s11069-006-9026-9.

Valentine GA. Damage to structures by pyroclastic flows and surges, inferred from nuclear weapons effects. J Volcanol Geotherm Res. 1998;87(1): 117-40. https://doi.org/10.1016/S0377-0273(98)00094-8.

Villasante-Marcos V, Pavón-Carrasco FJ. Palaeomagnetic constraints on the age of Lomo Negro volcanic eruption (El Hierro, Canary Islands). Geophys J Int. 2014;199(3):1497-514. https://doi.org/10.1093/gji/ggu346.

Voight B. The 1985 Nevado del Ruiz volcano catastrophe: anatomy and retrospection. J Volcanol Geotherm Res. 1990;42:151-88. https://doi.org/ 10.1016/0377-0273(90)90027-D.

Walker GP. Explosive volcanic eruptions - a new classification scheme. Geol Rundsch. 1973;62(2):431-46. https://doi.org/10.1007/bf01840108.

Ward SN, Day S. Cumbre Vieja Volcano-Potential collapse and tsunami at La Palma, Canary Islands. Geophys Res Lett. 2001;28(17):3397-400. https://doi. org/10.1029/2001GL013110. 
White JD, Schmincke HU. Phreatomagmaticeruptiveand depositional processes during the 1949 eruption on La Palma (Canary Islands). J Volcanol Geotherm Res. 1999;94(1-4):283-304. https://doi.org/10.1016/S0377-0273(99)00108-0.

Wohletz KH. Mechanisms of hydrovolcanic pyroclast formation: grain-size, scanning electron microscopy, and experimental studies. J Volcanol Geotherm Res. 1983;17(1):31-63. https://doi.org/10.1016/03770273(83)90061-6.

Woo G, Marzocchi W. Operational earthquake forecasting and decision-making: Springer; 2014, pp. 353-67. chap 18, https://doi.org/10.1007/978-3-64212233-0_18.

Zuccaro G, Cacace F, Spence R, Baxter P. Impact of explosive eruption scenarios at Vesuvius. J Volcanol Geotherm Res. 2008;178(3):416-53. https://doi.org/10.1016/j.jvolgeores.2008.01.005

\section{Publisher's Note}

Springer Nature remains neutral with regard to jurisdictional claims in published maps and institutional affiliations.

- fast, convenient online submission

- thorough peer review by experienced researchers in your field

- rapid publication on acceptance

- support for research data, including large and complex data types

- gold Open Access which fosters wider collaboration and increased citations

- maximum visibility for your research: over $100 \mathrm{M}$ website views per year

At BMC, research is always in progress.

Learn more biomedcentral.com/submissions 